\title{
Bromoform and dibromomethane in the tropics: a 3-D model study of chemistry and transport
}

\author{
R. Hossaini ${ }^{1}$, M. P. Chipperfield ${ }^{1}$, B. M. Monge-Sanz ${ }^{1}$, N. A. D. Richards ${ }^{1}$, E. Atlas $^{2}$, and D. R. Blake \\ ${ }^{1}$ Institute for Climate and Atmospheric Science, School of Earth and Environment, University of Leeds, UK \\ ${ }^{2}$ Rosenstiel School of Marine and Atmospheric Science, University of Miami, USA \\ ${ }^{3}$ Department of Chemistry, University of California, Irvine, USA
}

Received: 13 July 2009 - Published in Atmos. Chem. Phys. Discuss.: 7 August 2009

Revised: 19 December 2009 - Accepted: 30 December 2009 - Published: 25 January 2010

\begin{abstract}
We have developed a detailed chemical scheme for the degradation of the short-lived source gases bromoform $\left(\mathrm{CHBr}_{3}\right)$ and dibromomethane $\left(\mathrm{CH}_{2} \mathrm{Br}_{2}\right)$ and implemented it in the TOMCAT/SLIMCAT three-dimensional (3D) chemical transport model (CTM). The CTM has been used to predict the distribution of the two source gases (SGs) and 11 of their organic product gases (PGs). These first global calculations of the organic PGs show that their abundance is small. The longest lived organic PGs are $\mathrm{CBr}_{2} \mathrm{O}$ and $\mathrm{CHBrO}$, but their peak tropospheric abundance relative to the surface volume mixing ratio (vmr) of the SGs is less than $5 \%$. We calculate their mean local tropospheric lifetimes in the tropics to be $\sim 7$ and $\sim 2$ days (due to photolysis), respectively. Therefore, the assumption in previous modelling studies that SG degradation leads immediately to inorganic bromine seems reasonable.

We have compared observed tropical SG profiles from a number of aircraft campaigns with various model experiments. In the tropical tropopause layer (TTL) we find that the CTM run using p levels (TOMCAT) and vertical winds from analysed divergence overestimates the abundance of $\mathrm{CH}_{2} \mathrm{Br}_{2}$, and to a lesser extent $\mathrm{CHBr}_{3}$, although the data is sparse and comparisons are not conclusive. Better agreement in the TTL is obtained in the sensitivity run using $\theta$ levels (SLIMCAT) and vertical motion from diabatic heating rates. Trajectory estimates of residence times in the two model versions show slower vertical transport in the SLIMCAT $\theta$-level version. In the p-level model even when we switch off convection we still find significant amounts of the SGs considered may reach the cold point tropopause; the
\end{abstract}

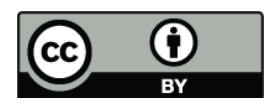

Correspondence to: R. Hossaini (chm3rh@leeds.ac.uk) stratospheric source gas injection (SGI) is only reduced by $\sim 16 \%$ for $\mathrm{CHBr}_{3}$ and $\sim 2 \%$ for $\mathrm{CH}_{2} \mathrm{Br}_{2}$ without convection.

Overall, the relative importance of the SG pathway and the PG pathway for transport of bromine to the stratospheric overworld $(\theta>380 \mathrm{~K})$ has been assessed. Assuming a 10-day washout lifetime of $\mathrm{Br}_{\mathrm{y}}$ in TOMCAT, we find the delivery of total $\mathrm{Br}$ from $\mathrm{CHBr}_{3}$ to be 0.72 pptv with $\sim 53 \%$ of this coming from SGI. Similary, for $\mathrm{CH}_{2} \mathrm{Br}_{2}$ we find a total $\mathrm{Br}$ value of $1.69 \mathrm{pptv}$ with $\sim 94 \%$ coming from SGI. We infer that these species contribute $\sim 2.4 \mathrm{pptv}$ of inorganic bromine to the lower stratosphere with SGI being the dominant pathway. Slower transport to and through the TTL would decrease this estimate.

\section{Introduction}

Bromine-containing very short-lived species (VSLS) are expected to provide an additional supply of inorganic bromine $\left(\mathrm{Br}_{\mathrm{y}}\right)$ to the stratosphere (e.g. WMO, 2007). Emissions of such species are predominately of natural oceanic origin and have been shown to exhibit large variability, particularly in tropical coastal regions that harbour substantial amounts of macro-algae (e.g. Quack and Wallace, 2003; Carpenter et al., 2009). It is also at tropical latitudes that deep convection allows the rapid ascent of such species from the marine boundary layer to the tropical tropopause layer (TTL). The rate of transport of these species to, and through, the TTL is currently under discussion (e.g. Krueger et al., 2008; Fueglistaler et al., 2009).

Current estimates of the contribution of inorganic bromine derived from VSLS $\left(\mathrm{Br}_{\mathrm{y}}^{\mathrm{VSLS}}\right)$ to the stratospheric $\mathrm{Br}_{\mathrm{y}}$ budget range from 3 to 8 pptv (Law and Sturges et al., 2007), with

Published by Copernicus Publications on behalf of the European Geosciences Union. 
a more recent value of approximately $5 \mathrm{pptv}$ derived by Dorf et al. (2008). Quantifying this additional source of bromine is important due to its role in catalytic ozone depletion in the stratosphere. In addition, it is expected that reactive $\mathrm{Br}_{\mathrm{y}}^{\mathrm{VSLS}}$ will impact tropospheric composition (e.g. Von Glasow et al., 2004).

Two distinct pathways have been identified leading to the arrival of $\mathrm{Br}_{\mathrm{y}}^{\mathrm{VSLS}}$ in the stratosphere; namely source gas injection (SGI) and product gas injection (PGI) (e.g. Ko and Poulet et al., 2003). SGI refers to the transport of a source gas (SG, e.g. bromoform, $\mathrm{CHBr}_{3}$ ) to the stratosphere, where upon degradation it will provide an in-situ source of $\mathrm{Br}_{\mathrm{y}}$. In contrast, PGI is the cross-tropopause transport of bromoorganic intermediates (e.g. $\mathrm{CBr}_{2} \mathrm{O}$ ) and also inorganic products (e.g. $\mathrm{HBr}, \mathrm{BrO}, \mathrm{Br}$ ), produced from $\mathrm{SG}$ degradation in the troposphere. The efficiency of both SGI and PGI depends largely upon the photochemical loss of source gases (mainly via reaction with $\mathrm{OH}$ or photolysis) and rate of removal of degradation products (via wet deposition) versus the timescale for troposphere-stratosphere transport. For this reason, it is of interest to investigate the impact of convection on this additional source of bromine, $\mathrm{Br}_{\mathrm{y}}^{\mathrm{VSLS}}$, in model experiments.

Previous model work has concentrated on quantifying $\mathrm{Br}_{\mathrm{y}}^{\mathrm{VSLS}}$ from the more abundant very short-lived source gases such as $\mathrm{CHBr}_{3}$. From a 2-D model study, Dvortsov et al. (1999) concluded that $\mathrm{CHBr}_{3}$ contributes around $1 \mathrm{pptv}$ additional $\mathrm{Br}_{\mathrm{y}}$ to the lower stratosphere (LS). Similarly, Nielsen and Douglass (2001) also derived a value of $1 \mathrm{pptv}$ from 3-D simulations with $\sim 50 \%$ of this from SGI. In both of these studies the lifetime of $\mathrm{Br}_{\mathrm{y}}$ following source gas degradation was assumed to be 10 days. More recently, Sinnhuber and Folkins (2006) used a 2-D mechanistic model of the tropical atmosphere to estimate that $\mathrm{CHBr}_{3}$ contributes between 0.8-2.1 pptv bromine via both SGI and PGI to the lower stratosphere with assumed $\mathrm{Br}_{\mathrm{y}}$ lifetimes of 10-100 days. From this study, the contribution from SGI was approximately $0.5 \mathrm{pptv}$. The most recent model study, Kerkweg et al. (2008), confirmed earlier suggestions that $\mathrm{CHBr}_{3}$ contributes "substantial amounts" of $\mathrm{Br}_{\mathrm{y}}$ to the lower stratosphere and that $\mathrm{Br}_{\mathrm{y}}^{\mathrm{VSLS}}$ should not be neglected in stratospheric modelling.

The impact of $\mathrm{Br}_{\mathrm{y}}^{\mathrm{VSLS}}$ in the stratosphere has been studied with multi-annual simulations by Feng et al. (2007) using the SLIMCAT 3-D chemical transport model (CTM). Salawitch et al. (2005) also performed a similar 2-D model study. Both studies report an $\sim 10$ DU decrease in the ozone column with an additional 6 pptv of $\mathrm{Br}_{\mathrm{y}}^{\mathrm{VSLS}}$ in the lower stratosphere. The impact of this additional bromine depends on the aerosol loading; the bromine causes a larger decrease in ozone when the aerosol loading is high and $\mathrm{ClO}$ is elevated.

The model studies discussed above have not directly considered the bromo-organic products (i.e. product gases, PGs) formed following source gas degradation. This omission is addressed in this study, which evaluates the contribution of
$\mathrm{CHBr}_{3}$ and $\mathrm{CH}_{2} \mathrm{Br}_{2}$ to the stratospheric $\mathrm{Br}$ budget, along with the relative contribution of SGI and PGI. Furthermore, results include novel estimates of the major and minor PGs formed following $\mathrm{CHBr}_{3}$ and $\mathrm{CH}_{2} \mathrm{Br}_{2}$ removal. Vertical source gas profiles are compared to measurements made during several aircraft campaigns in the tropical troposphere and near-tropopause regions. To date, there have been no measurements of organic PGs in the tropical atmosphere. We provide the first model estimates of the local lifetimes and abundances of these species in the tropical atmosphere.

Section 2 describes the derived chemical scheme for degradation of $\mathrm{CHBr}_{3}$ and $\mathrm{CH}_{2} \mathrm{Br}_{2}$. Kinetic and mechanistic assumptions are also discussed. Section 3 contains a description of the basic CTM setup, along with details of sensitivity runs carried out. Section 4 presents the model results. Conclusions and recommendations for future research are discussed in Sect. 5.

\section{Chemistry scheme}

Here we outline our chemical scheme to describe the tropospheric degradation of bromoform and dibromomethane. Reasonable mechanistic and kinetic assumptions have been made and are discussed. Kinetic data either is taken from Sander et al. (2006) (hereafter "JPL") or the Leeds Master Chemical Mechanism (hereafter "MCM", see http://mcm. leeds.ac.uk/MCM/). A summary of reactions and kinetic data used within the scheme is given in Tables 1 and 2 for $\mathrm{CHBr}_{3}$ and $\mathrm{CH}_{2} \mathrm{Br}_{2}$, respectively.

\subsection{Bromoform}

The degradation of $\mathrm{CHBr}_{3}$ has been examined in previous theoretical studies (e.g. McGivern et al., 2002, 2004). Its local tropospheric lifetime is $\sim 26$ days with photolysis being the dominant loss process (e.g. Ko and Poulet et al., 2003). Our bromoform scheme considers 7 organic species: $\mathrm{CHBr}_{3}$, $\mathrm{CBr}_{3} \mathrm{O}_{2}, \mathrm{CHBr}_{2} \mathrm{O}_{2}, \mathrm{CBr}_{3} \mathrm{OOH}, \mathrm{CHBr}_{2} \mathrm{OOH}, \mathrm{CBr}_{2} \mathrm{O}$ and $\mathrm{CHBrO}$ and is summarised in Fig. 1. The following subsections discuss the details of this scheme.

\subsubsection{Removal of $\mathrm{CHBr}_{3}$ source gas}

The scheme assumes removal of $\mathrm{CHBr}_{3}$ occurs via reaction with $\mathrm{OH} / \mathrm{Cl}$ radicals and also, more rapidly, by photolysis Reactions (R1-R3). The rates of reaction with $\mathrm{OH}$ and $\mathrm{Cl}\left(k_{1}, k_{2}\right)$ are calculated using the JPL recommended temperature-dependent expressions. The rate of photolysis $\left(j_{3}\right)$ is calculated using JPL absorption cross section data along with a parameterisation for their temperaturedependence (Moortgat et al., 1993). The quantum yield for $\mathrm{Br}$ atoms following $\mathrm{R} 3$ is assumed to be unity. It is also assumed that the immediate products of Reactions (R1-R3) $\left(\mathrm{CBr}_{3}\right.$ and $\left.\mathrm{CHBr}_{2}\right)$ will be rapidly oxidised under tropospheric conditions. 
Table 1. Summary of bromoform chemistry scheme. (a) Photolysis rates calculated from (where available) recommended absorption cross section data. (b) Paramaterisation for the temperature-dependence of SG absorption cross sections included. (c) Bry first-order loss due to washout adjusted to give lifetimes of 10, 20, 40 and $\infty$ days. (d) Rate constant estimated from reactions of analogous chlorine-containing species or generalised expression.

\begin{tabular}{|c|c|c|c|c|}
\hline & Reaction & Rate $/ \mathrm{cm}^{3}$ molecule $^{-1} \mathrm{~s}^{-1}$ & Comment & Ref. \\
\hline $\mathrm{R} 1$ & $\mathrm{CHBr}_{3}+\mathrm{OH}$ & $\mathrm{k}(\mathrm{T})=1.35 \mathrm{E}-12 . \exp (-600 / \mathrm{T})$ & - & JPL \\
\hline $\mathrm{R} 2$ & $\mathrm{CHBr}_{3}+\mathrm{Cl}$ & $\mathrm{k}(\mathrm{T})=4.85 \mathrm{E}-12 \cdot \exp (-850 / \mathrm{T})$ & - & JPL \\
\hline R3 & $\mathrm{CHBr}_{3}+\mathrm{h} v$ & $\mathbf{a}, \mathbf{b}$ & Assume quantum yield of 1 for $\mathrm{Br}$ & JPL \\
\hline $\mathrm{R} 4$ & $\mathrm{CBr}_{3} \mathrm{O}_{2}+\mathrm{NO}$ & $\mathrm{k}(\mathrm{T})=7.30 \mathrm{E}-12 . \exp (-270 / \mathrm{T})$ & d & JPL \\
\hline R5 & $\mathrm{CBr}_{3} \mathrm{O}_{2}+\mathrm{HO}_{2}$ & $\mathrm{k}(\mathrm{T})=3.30 \mathrm{E}-13 . \exp (820 / \mathrm{T})$ & d & $\mathrm{MCM}$ \\
\hline R6 & $\mathrm{CBr}_{3} \mathrm{O}_{2}+\mathrm{HO}_{2}$ & $\mathrm{k}(\mathrm{T})=3.30 \mathrm{E}-13 . \exp (820 / \mathrm{T})$ & As (R5) and equal partitioning of products & $\mathrm{MCM}$ \\
\hline $\mathrm{R} 7$ & $\mathrm{CHBr}_{2} \mathrm{O}_{2}+\mathrm{NO}$ & $\mathrm{k}(\mathrm{T})=2.54 \mathrm{E}-12 \cdot \exp (360 / \mathrm{T})$ & d & MCM \\
\hline $\mathrm{R} 8$ & $\mathrm{CHBr}_{2} \mathrm{O}_{2}+\mathrm{HO}_{2}$ & $\mathrm{k}(\mathrm{T})=3.30 \mathrm{E}-13 \cdot \exp (820 / \mathrm{T})$ & d & MCM \\
\hline R9 & $\mathrm{CHBr}_{2} \mathrm{O}_{2}+\mathrm{HO}_{2}$ & $\mathrm{k}(\mathrm{T})=3.30 \mathrm{E}-13 \cdot \exp (820 / \mathrm{T})$ & As (R8) and equal partitioning of products & MCM \\
\hline $\mathrm{R} 10$ & $\mathrm{CBr}_{3} \mathrm{OOH}+\mathrm{OH}$ & $\mathrm{k}(\mathrm{T})=1.90 \mathrm{E}-12 \cdot \exp (190 / \mathrm{T})$ & d & MCM \\
\hline $\mathrm{R} 11$ & $\mathrm{CBr}_{3} \mathrm{OOH}+\mathrm{h} v$ & $\mathbf{a}$ & Assume cross sections of $\mathrm{CH}_{3} \mathrm{OOH}$ & JPL \\
\hline $\mathrm{R} 12$ & $\mathrm{CHBr}_{2} \mathrm{OOH}+\mathrm{OH}$ & $\mathrm{k}(\mathrm{T})=1.90 \mathrm{E}-12 \cdot \exp (190 / \mathrm{T})$ & d & $\mathrm{MCM}$ \\
\hline $\mathrm{R} 13$ & $\mathrm{CHBr}_{2} \mathrm{OOH}+\mathrm{h} v$ & $\mathbf{a}$ & Assume cross sections of $\mathrm{CH}_{3} \mathrm{OOH}$ & JPL \\
\hline R14 & $\mathrm{CBr}_{2} \mathrm{O}+\mathrm{h} v$ & $\mathbf{a}$ & Assume quantum yield of 2 for $\mathrm{Br}$ & JPL \\
\hline $\mathrm{R} 15$ & $\mathrm{CHBrO}+\mathrm{h} v$ & $\mathbf{a}$ & Assume quantum yield of 1 for $\mathrm{Br}$ & JPL \\
\hline R16 & $\mathrm{Br}_{\mathrm{y}}$ washout & c & Variable in model - see text & \\
\hline
\end{tabular}

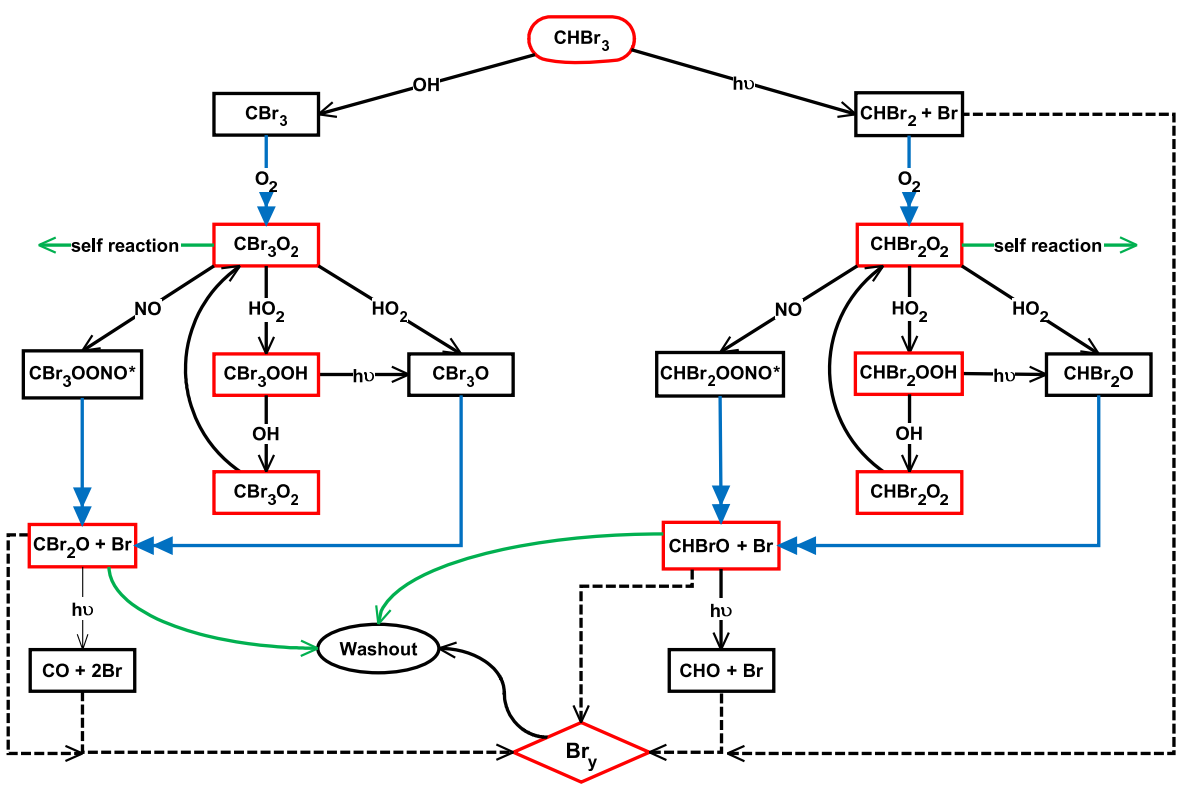

Fig. 1. Scheme for the tropospheric degradation of $\mathrm{CHBr}_{3}$. The red boxes denote the 9 organic species (1 SG+6 PGs) considered directly in the scheme, i.e. species whose production and loss are both calculated explicitly (see text). Black boxes denote species which are sufficiently short-lived for exclusion from the scheme. Blue lines therefore denote rapid reactions, dashed lines indicate the production of $\mathrm{Br}_{\mathrm{y}}$ and green denotes reactions not considered in the present scheme.

$$
\begin{aligned}
\mathrm{CHBr}_{3}+\mathrm{OH}\left(+\mathrm{O}_{2}\right) & \rightarrow \mathrm{CBr}_{3} \mathrm{O}_{2}+\mathrm{H}_{2} \mathrm{O} \\
\mathrm{CHBr}_{3}+\mathrm{Cl}\left(+\mathrm{O}_{2}\right) & \rightarrow \mathrm{CBr}_{3} \mathrm{O}_{2}+\mathrm{HCl} \\
\mathrm{CHBr}_{3}+\mathrm{h} v\left(+\mathrm{O}_{2}\right) & \rightarrow \mathrm{CHBr}_{2} \mathrm{O}_{2}+\mathrm{Br}
\end{aligned}
$$

\subsubsection{Removal of peroxy species}

The two peroxy radicals formed in Reactions (R1-R3) are assumed to be removed via reaction with $\mathrm{NO}$ and $\mathrm{HO}_{2} \mathrm{Re}-$ actions (R4-R9). Self-reaction of these species is deemed 
slow and is therefore not considered here. The $\mathrm{CBr}_{3} \mathrm{O}_{2}+\mathrm{NO}$ Reaction (R4) is assumed to produce $\mathrm{CBr}_{2} \mathrm{O}$, an expected major product of bromoform degradation (Ko and Poulet et al., 2003). Excited intermediates, such as $\mathrm{CBr}_{3} \mathrm{OONO}^{*}$ (not considered here), are expected to fragment rapidly to form $\mathrm{CBr}_{3} \mathrm{O}$, which itself would undergo a rapid decomposition to $\mathrm{CBr}_{2} \mathrm{O}$ (e.g. McGivern et al., 2002). The rate constant for Reaction (R4) $\left(k_{4}\right)$ is calculated using the recommended JPL expression for the analogous species $\mathrm{CCl}_{3} \mathrm{O}_{2}$. Similarly, rate constants for the $\mathrm{CBr}_{3} \mathrm{O}_{2}+\mathrm{HO}_{2}$ reactions $\left(k_{5}, k_{6}\right)$ are assumed equal (i.e. equal branching ratio of products) and taken from the MCM. These reactions produce $\mathrm{CBr}_{2} \mathrm{O}$ and the minor hydroperoxide product $\mathrm{CBr}_{3} \mathrm{OOH}$, respectively.

$$
\begin{aligned}
\mathrm{CBr}_{3} \mathrm{O}_{2}+\mathrm{NO} & \rightarrow \mathrm{CBr}_{2} \mathrm{O}+\mathrm{NO}_{2}+\mathrm{Br} \\
\mathrm{CBr}_{3} \mathrm{O}_{2}+\mathrm{HO}_{2} & \rightarrow \mathrm{CBr}_{2} \mathrm{O}+\mathrm{OH}+\mathrm{O}_{2}+\mathrm{Br} \\
\mathrm{CBr}_{3} \mathrm{O}_{2}+\mathrm{HO}_{2} & \rightarrow \mathrm{CBr}_{3} \mathrm{OOH}
\end{aligned}
$$

The reaction of $\mathrm{CHBr}_{2} \mathrm{O}_{2}+\mathrm{NO}$ Reaction (R7) is assumed to produce a second major product of bromoform degradation, namely formyl bromide (CHBrO). As for Reaction (R4) it is likely that Reaction (R7) would proceed via an excited intermediate (not considered here as sufficiently short-lived) such as $\mathrm{CHBr}_{2} \mathrm{OOH}^{*}$. The rate constant for this reaction $\left(k_{7}\right)$ is assumed equal to the analogous species $\mathrm{CHCl}_{2} \mathrm{O}_{2}$ and taken from the MCM. This is also the case for the $\mathrm{CHBr}_{2} \mathrm{O}_{2}+\mathrm{HO}_{2}$ Reactions (R8, R9) which produce $\mathrm{CHBrO}$ and the minor hydroperoxide, $\mathrm{CHBr}_{2} \mathrm{OOH}$ respectively. A further reaction pathway for these peroxy radicals (not considered here) is that with $\mathrm{NO}_{2}$. This would likely lead to the formation of Br-containing peroxynitrates (e.g. Ko and Poulet et al., 2003). In future versions of the degredation scheme these reactions will be considered.

$$
\begin{aligned}
\mathrm{CHBr}_{2} \mathrm{O}_{2}+\mathrm{NO} & \rightarrow \mathrm{CHBrO}+\mathrm{NO}_{2}+\mathrm{Br} \\
\mathrm{CHBr}_{2} \mathrm{O}_{2}+\mathrm{HO}_{2} & \rightarrow \mathrm{CHBrO}+\mathrm{OH}+\mathrm{O}_{2}+\mathrm{Br} \\
\mathrm{CHBr}_{2} \mathrm{O}_{2}+\mathrm{HO}_{2} & \rightarrow \mathrm{CHBr}{ }_{2} \mathrm{OOH}+\mathrm{O}_{2}
\end{aligned}
$$

\subsubsection{Removal of minor end products}

Removal of the two hydroperoxide species produced in Reactions (R6) and (R9) is assumed to be achieved via reaction with $\mathrm{OH}$ (Reactions R10, R12) and also by photolysis (Reactions R11, R13). Rate constants for the $\mathrm{OH}$ reactions are assumed equal to that of the analogous chlorine-containing species, $\mathrm{CCl}_{3} \mathrm{OOH}$ and $\mathrm{CHCl}_{2} \mathrm{OOH}$, from the MCM. The photolysis rates are calculated using the absorption cross sections of methylhydroperoxide $\left(\mathrm{CH}_{3} \mathrm{OOH}\right)$. Reaction of these hydroperoxides with $\mathrm{OH}$ leads to the reformation of the respective peroxy radical (initially formed in Reactions R1 and $\mathrm{R} 3)$.

$$
\begin{aligned}
& \mathrm{CBr}_{3} \mathrm{OOH}+\mathrm{OH} \rightarrow \mathrm{CBr}_{3} \mathrm{O}_{2}+\mathrm{H}_{2} \mathrm{O} \\
& \mathrm{CBr}_{3} \mathrm{OOH}+\mathrm{h} v \rightarrow \mathrm{CBr}_{2} \mathrm{O}+\mathrm{OH}+\mathrm{Br} \\
& \mathrm{CHBr} 2 \mathrm{OOH}+\mathrm{OH} \rightarrow \mathrm{CHBr}_{2} \mathrm{O}_{2}+\mathrm{H}_{2} \mathrm{O} \\
& \mathrm{CHBr} 2 \mathrm{OOH}+\mathrm{h} v \rightarrow \mathrm{CHBrO}+\mathrm{OH}+\mathrm{Br}
\end{aligned}
$$

\subsubsection{Removal of major end products and $\mathrm{Br}_{\mathrm{y}}$}

Removal of the major products of bromoform degradation, $\mathrm{CBr}_{2} \mathrm{O}$ and $\mathrm{CHBrO}$, is assumed to occur via photolysis ( $\mathrm{Re}-$ actions $\mathrm{R} 14, \mathrm{R} 15)$. For $\mathrm{CBr}_{2} \mathrm{O}+\mathrm{h} v$ we assume a yield of two $\mathrm{Br}$ atoms, with other photolysis pathways, such as that leading to $\mathrm{HBr}$ production, not considered. Similarly, for $\mathrm{CHBrO}+\mathrm{h} v$ it is assumed the quantum yield for $\mathrm{Br}$ atoms is unity. Photolysis rates for both reactions are calculated using the recommended JPL cross section data.

$$
\begin{aligned}
\mathrm{CBr}_{2} \mathrm{O}+\mathrm{h} v & \rightarrow \mathrm{CO}+2 \mathrm{Br} \\
\mathrm{CHBrO}+\mathrm{h} v & \rightarrow \mathrm{CHO}+\mathrm{Br}
\end{aligned}
$$

In the current scheme all inorganic bromine species produced are grouped together as $\mathrm{Br}_{\mathrm{y}}$ without any further partitioning. Depending on the model run (see Sect. 3.2), Bry is removed in the troposphere by washout given a specified assumed lifetime.

$\mathrm{Br}_{\mathrm{y}} \rightarrow$ washout

\subsection{Dibromomethane}

The degradation of $\mathrm{CH}_{2} \mathrm{Br}_{2}$ has also been examined in previous theoretical studies (e.g. McGivern et al., 2002, 2004). The local tropospheric lifetime is quoted as $\sim 120$ days with reaction with $\mathrm{OH}$ being the dominant loss process (Ko and Poulet et al., 2003). Our scheme considers six organic species, $\mathrm{CH}_{2} \mathrm{Br}_{2}, \mathrm{CHBr}_{2} \mathrm{O}_{2}, \mathrm{CH}_{2} \mathrm{BrO}_{2}$, $\mathrm{CHBrO}, \mathrm{CHBr}_{2} \mathrm{OOH}$ and $\mathrm{CH}_{2} \mathrm{BrOOH}$. The major products of $\mathrm{CH}_{2} \mathrm{Br}_{2}$ degradation are expected to be $\mathrm{CHBrO}$ and $\mathrm{Br}_{\mathrm{y}}$ with $\mathrm{CHBr}_{2} \mathrm{OOH}$ being a minor product.

\subsubsection{Removal of $\mathrm{CH}_{2} \mathrm{Br}_{2}$ source gas}

Our scheme assumes removal of $\mathrm{CH}_{2} \mathrm{Br}_{2}$ is achieved via reaction with $\mathrm{OH} / \mathrm{Cl}$ radicals and also, less rapidly, by photolysis (Reactions R17-R19). The rates of reaction with $\mathrm{OH}$ and $\mathrm{Cl}\left(k_{17}, k_{18}\right)$ are calculated using the JPL temperaturedependent expressions. The rate of photolysis $\left(j_{19}\right)$ is calculated using JPL absorption cross section data at 295-298 K. The quantum yield for $\mathrm{Br}$ atoms is assumed to be unity. As for the $\mathrm{CHBr}_{3}$ scheme, it is assumed that following $\mathrm{H}$ abstraction and photolysis, the immediate products of source gas degradation $\left(\mathrm{CHBr}_{2}, \mathrm{CH}_{2} \mathrm{Br}\right)$ will be rapidly oxidised under tropospheric conditions forming associated peroxy radicals. 
Table 2. As Table 1 but for dibromomethane.

\begin{tabular}{|c|c|c|c|c|}
\hline & Reaction & Rate $/ \mathrm{cm}^{3}$ molecule ${ }^{-1} \mathrm{~s}^{-1}$ & Comment & Ref. \\
\hline $\mathrm{R} 17$ & $\mathrm{CH}_{2} \mathrm{Br}_{2}+\mathrm{OH}$ & $\mathrm{k}(\mathrm{T})=2.00 \mathrm{E}-12 . \exp (-840 / \mathrm{T})$ & - & JPL \\
\hline $\mathrm{R} 18$ & $\mathrm{CH}_{2} \mathrm{Br}_{2}+\mathrm{Cl}$ & $\mathrm{k}(\mathrm{T})=6.30 \mathrm{E}-12 . \exp (-800 / \mathrm{T})$ & - & JPL \\
\hline R19 & $\mathrm{CH}_{2} \mathrm{Br}_{2}+\mathrm{h} v$ & 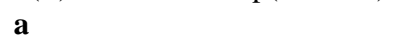 & Assume quantum yield of 1 for $\mathrm{Br}$ & JPL \\
\hline $\mathrm{R} 20$ & $\mathrm{CHBr}_{2} \mathrm{O}_{2}+\mathrm{NO}$ & $\mathrm{k}(\mathrm{T})=2.54 \mathrm{E}-12 . \exp (360 / \mathrm{T})$ & As Table 1 (R7) & \\
\hline $\mathrm{R} 21$ & $\mathrm{CHBr}_{2} \mathrm{O}_{2}+\mathrm{HO}_{2}$ & $\mathrm{k}(\mathrm{T})=3.30 \mathrm{E}-13 . \exp (820 / \mathrm{T})$ & As Table 1 (R8) & \\
\hline $\mathrm{R} 22$ & $\mathrm{CHBr}_{2} \mathrm{O}_{2}+\mathrm{HO}_{2}$ & $\mathrm{k}(\mathrm{T})=3.30 \mathrm{E}-13 . \exp (820 / \mathrm{T})$ & As Table 1 (R9) & \\
\hline $\mathrm{R} 23$ & $\mathrm{CH}_{2} \mathrm{BrO}_{2}+\mathrm{NO}$ & $\mathrm{k}(\mathrm{T})=4.00 \mathrm{E}-13 . \exp (300 / \mathrm{T})$ & d & MCM \\
\hline $\mathrm{R} 24$ & $\mathrm{CH}_{2} \mathrm{BrO}_{2}+\mathrm{HO}_{2}$ & $\mathrm{k}(\mathrm{T})=3.30 \mathrm{E}-13 . \exp (820 / \mathrm{T})$ & d & MCM \\
\hline $\mathrm{R} 25$ & $\mathrm{CH}_{2} \mathrm{BrO}_{2}+\mathrm{HO}_{2}$ & $\mathrm{k}(\mathrm{T})=3.30 \mathrm{E}-13 . \exp (820 / \mathrm{T})$ & As (R24) and equal partitioning of products & MCM \\
\hline R26 & $\mathrm{CHBr}_{2} \mathrm{OOH}+\mathrm{OH}$ & $\mathrm{k}(\mathrm{T})=1.90 \mathrm{E}-12 . \exp (190 / \mathrm{T})$ & As Table 1 (R12) & \\
\hline $\mathrm{R} 27$ & $\mathrm{CHBr}_{2} \mathrm{OOH}+\mathrm{h} v$ & $\mathbf{a}$ & As Table 1 (R13) & \\
\hline R28 & $\mathrm{CH}_{2} \mathrm{BrOOH}+\mathrm{OH}$ & $\mathrm{k}(\mathrm{T})=1.90 \mathrm{E}-12 . \exp (190 / \mathrm{T})$ & d & MCM \\
\hline R29 & $\mathrm{CH}_{2} \mathrm{BrOOH}+\mathrm{h} v$ & $\mathbf{a}$ & Assume cross sections of $\mathrm{CH}_{3} \mathrm{OOH}$ & JPL \\
\hline $\mathrm{R} 30$ & $\mathrm{CHBrO}+\mathrm{h} v$ & $\mathbf{a}$ & As Table $1(\mathrm{R} 15)$ & \\
\hline R31 & $\mathrm{Br}_{\mathrm{y}}$ washout & c & As Table 1 (R16) & \\
\hline
\end{tabular}

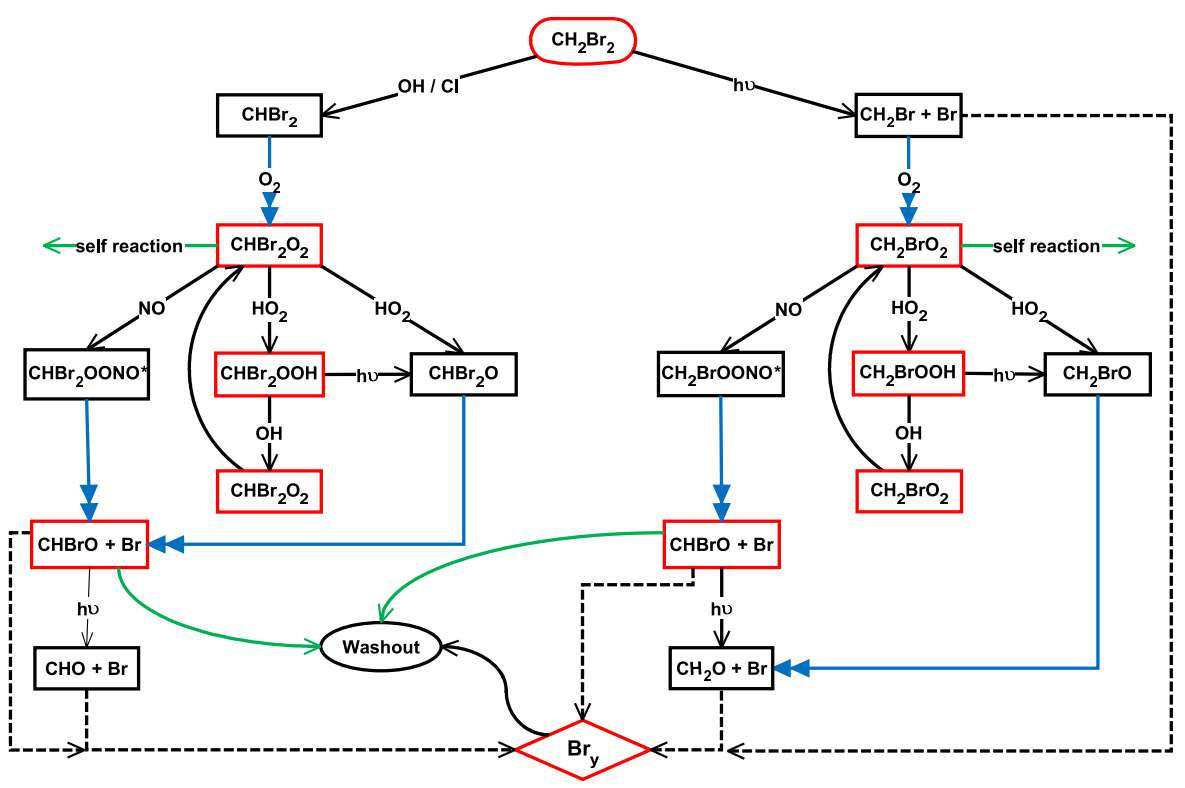

Fig. 2. As Fig. 1 but for $\mathrm{CH}_{2} \mathrm{Br}_{2}$.

$$
\begin{aligned}
\mathrm{CH}_{2} \mathrm{Br}_{2}+\mathrm{OH}\left(+\mathrm{O}_{2}\right) & \rightarrow \mathrm{CHBr}_{2} \mathrm{O}_{2}+\mathrm{H}_{2} \mathrm{O} \\
\mathrm{CH}_{2} \mathrm{Br}_{2}+\mathrm{Cl}\left(+\mathrm{O}_{2}\right) & \rightarrow \mathrm{CHBr}_{2} \mathrm{O}_{2}+\mathrm{HCl} \\
\mathrm{CH}_{2} \mathrm{Br}_{2}+\mathrm{h} v\left(+\mathrm{O}_{2}\right) & \rightarrow \mathrm{CH}_{2} \mathrm{BrO}_{2}+\mathrm{Br}
\end{aligned}
$$

\subsubsection{Removal of peroxy species}

The two peroxy radicals formed in Reactions (R17-R19) are assumed to be removed via reaction with $\mathrm{NO}$ and $\mathrm{HO}_{2}$. Loss of $\mathrm{CHBr}_{2} \mathrm{O}_{2}$ via these Reactions ( $\left.\mathrm{R} 20-\mathrm{R} 22\right)$ is treated as that described in Sect. 2.1.2 for the bromoform scheme.

$$
\mathrm{CHBr}_{2} \mathrm{O}_{2}+\mathrm{NO} \rightarrow \mathrm{CHBrO}+\mathrm{NO}_{2}+\mathrm{Br}
$$

$$
\begin{aligned}
& \mathrm{CHBr}_{2} \mathrm{O}_{2}+\mathrm{HO}_{2} \rightarrow \mathrm{CHBrO}+\mathrm{OH}+\mathrm{O}_{2}+\mathrm{Br} \\
& \mathrm{CHBr}_{2} \mathrm{O}_{2}+\mathrm{HO}_{2} \rightarrow \mathrm{CHBr} 2 \mathrm{OOH}+\mathrm{O}_{2}
\end{aligned}
$$

The $\mathrm{CH}_{2} \mathrm{BrO}_{2}+\mathrm{NO}$ Reaction (R23) is assumed to produce $\mathrm{NO}_{2}$ and $\mathrm{Br}_{\mathrm{y}}$. The rate constant for this reaction $\left(k_{23}\right)$ is calculated using the recommended JPL expression. For reactions with $\mathrm{HO}_{2}$ Reaction (R24, R25), rate constants are taken from the MCM. The products of these reactions are $\mathrm{Br}_{\mathrm{y}}$ and the hydroperoxide $\mathrm{CH}_{2} \mathrm{BrOOH}$, respectively.

$$
\begin{aligned}
\mathrm{CH}_{2} \mathrm{BrO}_{2}+\mathrm{NO} & \rightarrow \mathrm{CH}_{2} \mathrm{O}+\mathrm{NO}_{2}+\mathrm{Br} \\
\mathrm{CH}_{2} \mathrm{BrO}_{2}+\mathrm{HO}_{2} & \rightarrow \mathrm{CH}_{2} \mathrm{O}+\mathrm{OH}+\mathrm{O}_{2}+\mathrm{Br} \\
\mathrm{CH}_{2} \mathrm{BrO}_{2}+\mathrm{HO}_{2} & \rightarrow \mathrm{CH}_{2} \mathrm{BrOOH}+\mathrm{O}_{2}
\end{aligned}
$$




\subsubsection{Removal of end products}

Removal of CHBrO Reaction (R26), produced in Reactions (R20) and (R21), is achieved via photolysis as discussed in Sect. 2.1.3. Similarly removal of $\mathrm{CHBr}_{2} \mathrm{OOH}$ (Reactions R27, R28) produced in Reaction (R22) is analogous to removal in Reactions (R12) and (R13) (i.e. by reaction with $\mathrm{OH}$ and by photolysis respectively). Removal of $\mathrm{CH}_{2} \mathrm{BrOOH}$, produced in Reaction (R25), has yet to be considered and is also assumed to be removed via reaction with $\mathrm{OH}$ (Reaction R29) and also by photolysis (Reaction R30). The rate constant for the $\mathrm{OH}$ reaction $\left(k_{29}\right)$ is taken from the $\mathrm{MCM}$ and the reaction products are expected to be the peroxy species $\mathrm{CH}_{2} \mathrm{BrO}_{2}$ and water. The photolysis rate $\left(j_{30}\right)$ is calculated using the cross sections of $\mathrm{CH}_{3} \mathrm{OOH}$.

$$
\begin{aligned}
\mathrm{CH}_{2} \mathrm{BrOOH}+\mathrm{OH} & \rightarrow \mathrm{CH}_{2} \mathrm{BrO}_{2}+\mathrm{H}_{2} \mathrm{O} \\
\mathrm{CH}_{2} \mathrm{BrOOH}+\mathrm{h} v & \rightarrow \mathrm{CH}_{2} \mathrm{O}+\mathrm{OH}+\mathrm{Br}
\end{aligned}
$$

\section{Model and experiments}

\subsection{TOMCAT/SLIMCAT 3-D CTM}

TOMCAT is an off-line 3-D CTM described in detail by Chipperfield (2006). The model has performed well in previous tropospheric studies and has been shown to simulate key chemistry and transport reasonably (e.g. Arnold et al., 2005). The model uses the Prather (1986) conservation of secondorder moments advection scheme, a parameterisation of convection (Stockwell and Chipperfield, 1998) and also a parameterisation of boundary layer mixing (Holtslag and Boville, 1993). The CTM in TOMCAT mode uses a terrain-following hybrid $\sigma-p$ vertical coordinate and diagnoses the large-scale vertical motion from divergence. The CTM has an option ("SLIMCAT") for running with isentropic $(\theta)$ levels in the upper troposphere and stratosphere with the vertical motion calculated from heating rates. The SLIMCAT model only considers transport by large-scale advection; there is no parameterisation of convection and boundary layer mixing. The CTM includes a scheme to calculate trajectories (e.g. MongeSanz et al., 2007).

\subsection{Simulations}

In all TOMCAT simulations described here (see Table 3 ) the resolution of the model was $5.6^{\circ} \times 5.6^{\circ}$ with 38 (or 31) vertical levels $(\sim 1 \mathrm{~km}$ deep in mid troposphere) extending from the surface to $\sim 35 \mathrm{~km}$. The model was forced using the European Centre for Medium-Range Weather Forecasts (ECMWF) 6-hourly analyses. The model was initialised on 1 January 2006 and run for 2 years. Year 1 was treated as model spin-up and year 2 output (2007) was saved every 3.75 days for analysis. SLIMCAT simulations differed in that the model was spun up for 7 years, due to the slower circulation, prior to analysis of 2007 output.

For the "base run" (run B), the TOMCAT model included specified oxidant fields along with the $\mathrm{CHBr}_{3}$ and $\mathrm{CH}_{2} \mathrm{Br}_{2}$ degradation schemes described in Sect. 2. Monthly mean diurnal mean fields of the concentration of fixed species (e.g. $\mathrm{OH}, \mathrm{NO}, \mathrm{HO}_{2}$ ) were read from a previous TOMCAT full chemistry run for 2005. The background concentration of atomic chlorine, which was not calculated in the tropospheric full chemistry run, was set to $1 \times 10^{4}$ molecules $\mathrm{cm}^{-3}$. The model chemical scheme used a climatological tropical ozone profile for photolysis calculations (Chipperfield, 1999).

Figure 3 shows example tropical zonal mean profiles of temperature and the primary oxidant $\mathrm{OH}$. The mixing ratio of $\mathrm{CHBr}_{3}$ and $\mathrm{CH}_{2} \mathrm{Br}_{2}$ source gases were fixed uniformly in space and time at $1.2 \mathrm{pptv}$ in the bottom two layers of the model in the tropical regions $\left( \pm 20^{\circ}\right)$. This value is typical for both mean $\mathrm{CHBr}_{3}$ and $\mathrm{CH}_{2} \mathrm{Br}_{2}$ in the marine boundary layer (MBL). Quack and Wallace (2003) report background MBL $\mathrm{CHBr}_{3}$ in the range $0.5-1.5$ pptv. Similarly for $\mathrm{CH}_{2} \mathrm{Br}_{2}$, Butler et al. (2007) report $\mathrm{CH}_{2} \mathrm{Br}_{2}$ in the range 0.6-1.3 pptv for the tropical MBL. Furthermore, the use of a SG volume mixing ratio (vmr) of 1.2 pptv provides the best fit to observed profiles (see Sect. 4). In this study we are interested in the relative mixing ratios of bromine species in the TTL compared to the surface and we do not need to introduce the complication of specifying uncertain emission fluxes. All other advected tracers were initialised at zero at the start of the simulation. The lifetime of $\mathrm{Br}_{\mathrm{y}}$ was assumed to be infinite for run $\mathbf{B}$. A number of sensitivity runs were also performed. Run $\mathbf{S}_{\mathrm{NOCONV}}$ differed from run $\mathbf{B}$ in that model convection was switched off (note, mixing in the PBL remained switched on). Runs $\mathbf{S}_{10}, \mathbf{S}_{20}$ and $\mathbf{S}_{40}$ differed from run $\mathbf{B}$ in that the lifetime of $\mathrm{Br}_{\mathrm{y}}$ was set to 10,20 and 40 days below the cold-point tropopause (CPT), respectively. Run $\mathbf{S}_{2 \mathrm{OH}}$ differed from the base in that model $[\mathrm{OH}]$ was doubled. Run $\mathbf{S}_{\mathrm{L} 31}$ differed in that the model employed coarser vertical resolution (factor of 2) above $\sim 300 \mathrm{hPa}$ and therefore had only 31 levels. Finally, SLIMCAT simulations were also carried out in which artificial mixing in the tropical troposphere was assumed by fixing both $\mathrm{CHBr}_{3}$ and $\mathrm{CH}_{2} \mathrm{Br}_{2}$ SGs in the lower 8 levels of the SLIMCAT $\sigma-\theta$ model (surface to $\sim 10 \mathrm{~km}$ ). For run $\mathbf{S}_{\text {SLIMCAT }}$ the assumed lifetime of $\mathrm{Br}_{\mathrm{y}}$ due to washout was infinite. For runs $\mathbf{S}_{\text {SLIMCaT10, }}$ $\mathbf{S}_{\text {SLIMCAT20 }}$ and $\mathbf{S}_{\text {SLIMCAT40 }}$ the assumed lifetime of $\mathrm{Br}_{\mathrm{y}}$ was 10, 20 and 40 days respectively. It should be noted that for SLIMCAT simulations (due to the artificial mixing in the troposphere) the assumed washout is only "switched on" between $\sim 10-17 \mathrm{~km}$. All other aspects of chemistry were consistent between the two models. 
Table 3. CTM experiments performed.

\begin{tabular}{lllll}
\hline Run & Convection & Bry lifetime & Vertical levels & {$[\mathrm{OH}]$} \\
\hline $\mathbf{B}$ & yes & Infinite & 38 & $1 \mathbf{x}$ \\
$\mathbf{S}_{\text {NOCONV }}$ & no & Infinite & 38 & $1 \mathbf{x}$ \\
$\mathbf{S}_{10}$ & yes & 10 days below cold-point & 38 & $1 \mathbf{x}$ \\
$\mathbf{S}_{20}$ & yes & 20 days below cold-point & 38 & $1 \mathrm{x}$ \\
$\mathbf{S}_{40}$ & yes & 40 days below cold-point & 38 & $1 \mathbf{x}$ \\
$\mathbf{S}_{2 \mathrm{OH}}$ & yes & Infinite & 38 & $2 \mathrm{x}$ \\
$\mathbf{S}_{\text {L31 }}$ & yes & Infinite & 31 & $1 \mathbf{x}$ \\
$\mathbf{S}_{\text {SLIMCAT }}$ & no & Infinite & $38(\sigma-\theta)$ & $1 \mathbf{x}$ \\
$\mathbf{S}_{\text {SLIMCAT10 }}$ & no & 10 days below cold-point & $38(\sigma-\theta)$ & $1 \mathbf{x}$ \\
$\mathbf{S}_{\text {SLIMCAT20 }}$ & no & 20 days below cold-point & $38(\sigma-\theta)$ & $1 \mathbf{x}$ \\
$\mathbf{S}_{\text {SLIMCAT40 }}$ & no & 40 days below cold-point & $38(\sigma-\theta)$ & $1 \mathbf{x}$ \\
\hline
\end{tabular}

Table 4. Mean modelled lifetimes (days) of $\mathrm{CHBr}_{3}$ and $\mathrm{CH}_{2} \mathrm{Br}_{2}$ in the tropics in different regions from the surface to cold-point ( $\sim 17 \mathrm{~km}, \sim 95 \mathrm{hPa})$. Lifetime with respect to photolysis $\left(\tau_{\mathrm{h} v}\right), \mathrm{OH}$ $\left(\tau_{\mathrm{OH}}\right)$ and overall local lifetime $\left(\tau_{\text {local }}\right)$.

\begin{tabular}{lllll}
\hline Source Gas & Pressure/hPa & $\tau_{\mathrm{h} \nu} /$ days & $\tau_{\mathrm{OH}} /$ days & $\tau_{\text {local }} /$ days \\
\hline $\mathrm{CHBr}_{3}$ & 1000 & 28 & 35 & 16 \\
$\mathrm{CHBr} 3$ & $1000-500$ & 28 & 42 & 17 \\
$\mathrm{CHBr} 3$ & $500-200$ & 25 & 132 & 21 \\
$\mathrm{CHBr}$ & $200-95$ & 33 & 292 & 29 \\
& & & & \\
$\mathrm{CH}_{2} \mathrm{Br}_{2}$ & 1000 & 21004 & 53 & 52 \\
$\mathrm{CH}_{2} \mathrm{Br}_{2}$ & $1000-500$ & 20495 & 66 & 65 \\
$\mathrm{CH}_{2} \mathrm{Br}_{2}$ & $500-200$ & 13231 & 243 & 237 \\
$\mathrm{CH}_{2} \mathrm{Br}_{2}$ & $200-95$ & 2535 & 655 & 453 \\
\hline
\end{tabular}

\section{Results and discussion}

\subsection{Source gas injection}

Figure 4 shows the mean modelled loss rates (due to reaction with $\mathrm{OH}$ and photolysis) and the local photochemical lifetimes for $\mathrm{CHBr}_{3}$ and $\mathrm{CH}_{2} \mathrm{Br}_{2}$ in the tropics. Results from this analysis are also summarised in Table 4. For $\mathrm{CHBr}_{3}$, the dominant loss process is photolysis. The calculated local lifetime of $\mathrm{CHBr}_{3}\left(\tau_{\text {local }}\right)$ ranges between $\sim 25-30$ days in the TTL and has a surface value of $\sim 15$ days. This is generally consistent with previous model calculations (e.g. Warwick et al., 2006; Sinnhuber and Folkins, 2006). For $\mathrm{CH}_{2} \mathrm{Br}_{2}$, in the mid-troposphere loss is dominated by reaction with $\mathrm{OH}$ with photolysis being slow. At the CPT, the two loss channels are roughly equal. The local lifetime of $\mathrm{CH}_{2} \mathrm{Br}_{2}$ ranges from $\sim 50$ days at the surface to a maximum of $\sim 520$ days in the TTL. This is somewhat large given the working definition of a VSLS as a species whose lifetime is less than 6 months (Law and Sturges et al., 2007).
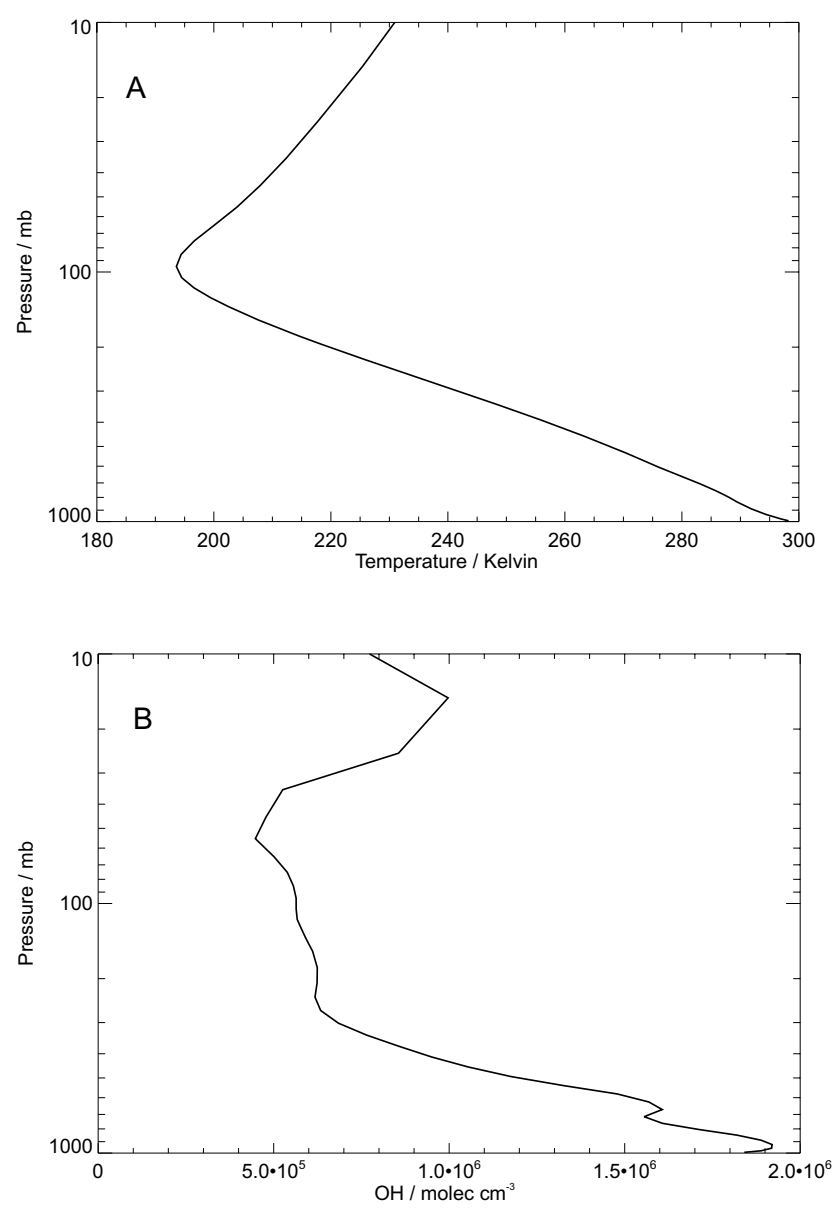

Fig. 3. Tropical $\left( \pm 20^{\circ}\right.$ latitude $)$ annual mean zonal mean profiles of (a, top) temperature (K) from model run B (i.e. ECMWF analyses) and (b, bottom) specified (24-h mean) $\mathrm{OH}$ concentration profile used in CTM experiments. 

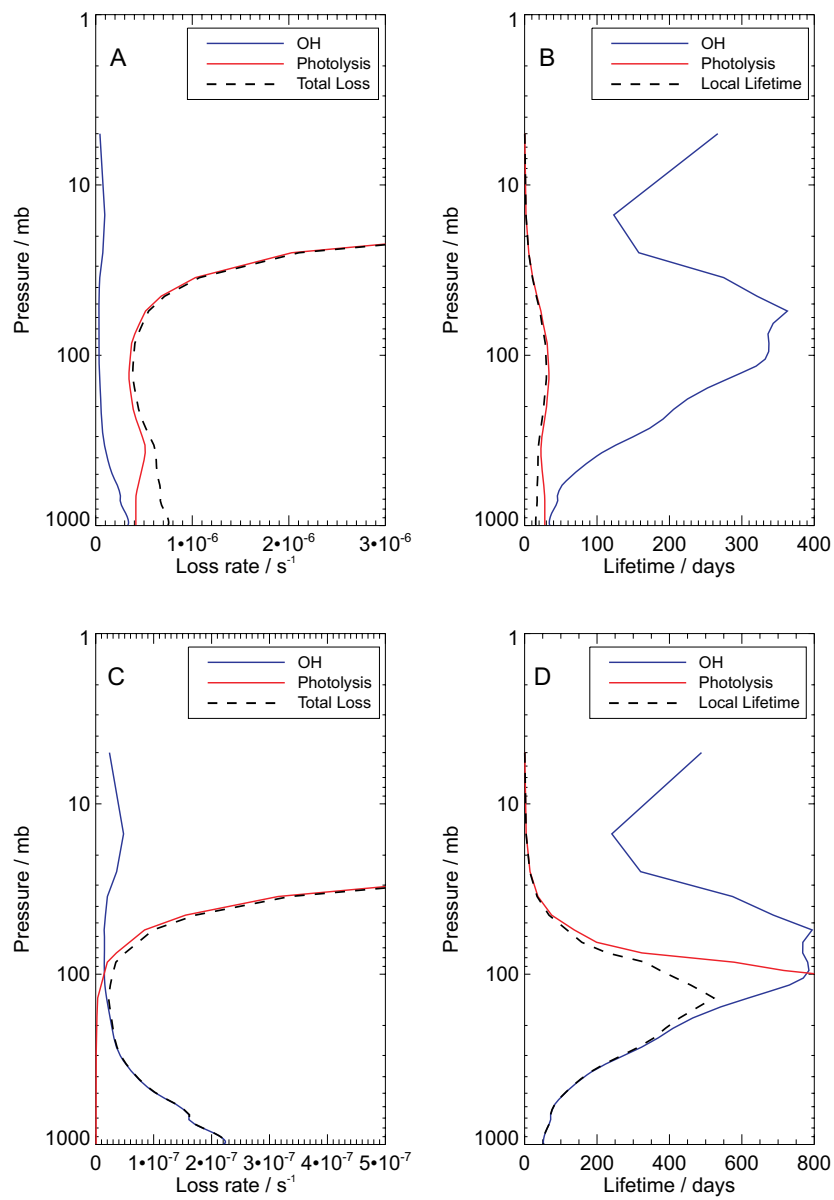

Fig. 4. Tropical $\left( \pm 20^{\circ}\right.$ latitude $)$ annual mean zonal mean profiles of (a, top left) $\mathrm{CHBr}_{3}$ loss rate $\left(\mathrm{s}^{-1}\right)$ due to photolysis (red line), reaction with $\mathrm{OH}$ (blue line), and the overall total (black dashed line), and (b, top right) $\mathrm{CHBr}_{3}$ lifetime (days) due to the same processes from the TOMCAT model runs. Panels (c, bottom left) and (d, bottom right) are the equivalent panels for $\mathrm{CH}_{2} \mathrm{Br}_{2}$.

Figure 5 shows the tropical zonal mean profiles for the source gases $\mathrm{CHBr}_{3}$ and $\mathrm{CH}_{2} \mathrm{Br}_{2}$ from the base run $\mathbf{B}$ and sensitivity runs $\mathbf{S}_{\mathrm{NOCONV}}$ (no convection), $\mathbf{S}_{2 \mathrm{OH}}(2 \times[\mathrm{OH}])$ and $\mathbf{S}_{\text {SLIMCAT. The location of the CPT and the approximate }}$ base of the TTL is shown for reference. Note that we define the base of the TTL as the level of maximum convective outflow (approximately $12 \mathrm{~km}$ ) and the top of the TTL as the cold-point (e.g. Law and Sturges et al., 2007). The results here show that with the full TOMCAT model transport (run B) the mean $\mathrm{CHBr}_{3}$ mixing ratio at the $\mathrm{CPT}(\sim 17 \mathrm{~km})$ is $\sim 0.126$ pptv resulting in an SGI contribution of $\sim 0.38 \mathrm{pptv}$ of $\mathrm{Br}_{\mathrm{y}}$ to the lower stratosphere. This is in general agreement with the SGI value of 0.5 pptv predicted by Sinnhuber and Folkins (2006). Similarly for $\mathrm{CH}_{2} \mathrm{Br}_{2}$, run $\mathbf{B}$ predicts a mean of 0.797 pptv of $\mathrm{SG}$ at the tropopause, resulting in a value for SGI of $\sim 1.59 \mathrm{pptv}$; i.e. over $4 \times$ that of bromoform. Without convection (run $\mathbf{S}_{\mathrm{NOCONV}}$ ) the SGI values
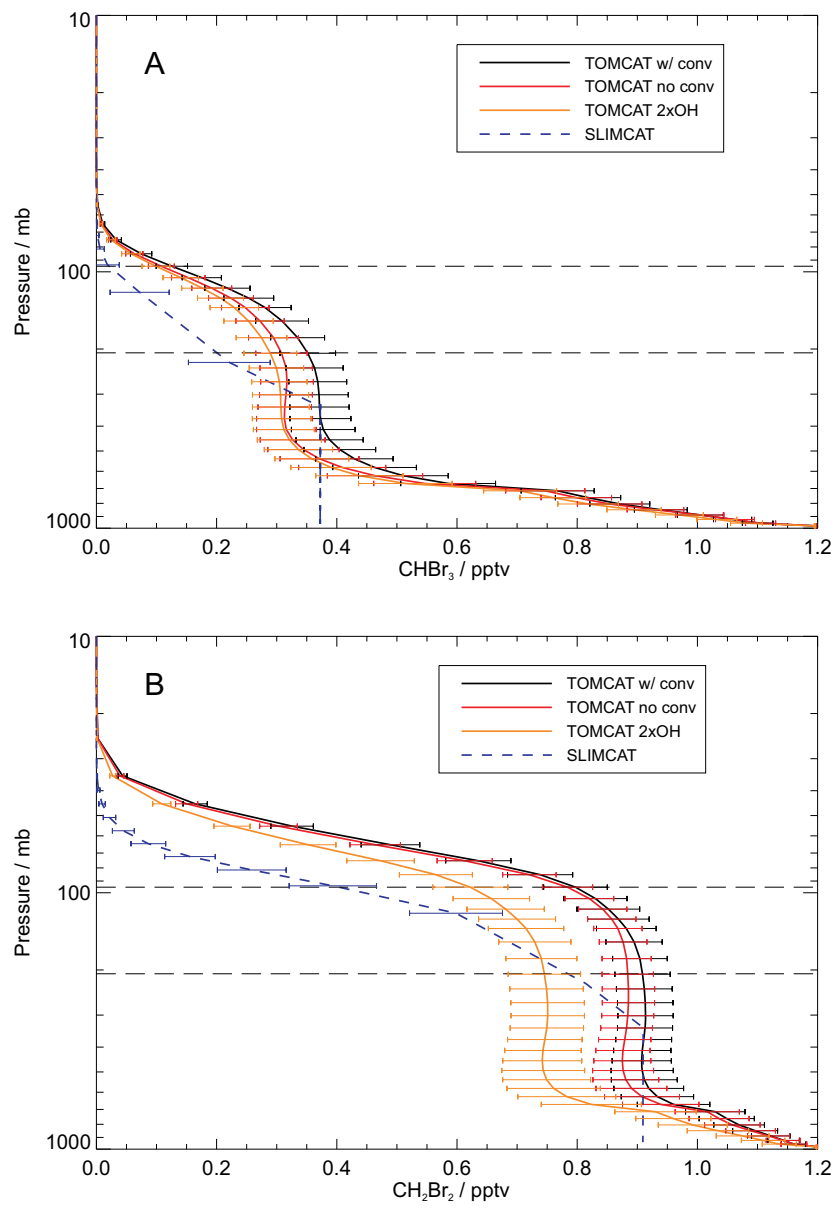

Fig. 5. Tropical $\left( \pm 20^{\circ}\right.$ latitude $)$ annual mean zonal mean modelled profiles of (a) $\mathrm{CHBr}_{3}$ and (b) $\mathrm{CH}_{2} \mathrm{Br}_{2}$. Black line denotes output from the run $\mathbf{B}$ (i.e. with convection), red line denotes output from sensitivity run $\mathbf{S}_{\mathrm{NOCONV}}$ (no convection), orange line from run $\mathbf{S}_{2 \mathrm{OH}}$ and dashed blue line from run $\mathbf{S}_{\mathrm{SLIMCAT}}$. Variability in time and space shown with \pm 1 standard deviation. The location of the cold-point tropopause (CPT) and the base of the TTL (black dashed lines) are shown for reference.

reduce to $0.32 \mathrm{pptv}$ and $1.57 \mathrm{pptv}$, i.e. $\sim 84 \%$ and $\sim 98 \%$ of run $\mathbf{B}$ values for $\mathrm{CHBr}_{3}$ and $\mathrm{CH}_{2} \mathrm{Br}_{2}$, respectively. These results suggest that SGI via both species is not overly sensitive to model parameterised convection, particularly at the CPT. For $\mathrm{CHBr}_{3}$, this apparently contradicts the findings of Nielsen and Douglass (2001) who report a treatment of convection is required in their model simulations in order for $\mathrm{CHBr}_{3}$ to reach the tropical lower stratosphere. Similarly, Warwick et al. (2006) report from a 3-D model study $\mathrm{CHBr}_{3}$ to be highly dependent on convection in the tropical upper troposphere. Without further details on the experiments performed in these other studies we cannot comment further on the differences. In our experiments, although we switch off convection we still include the parameterisation of mixing in the PBL which causes mixing of surface-emitted tracers 
in the bottom few $\mathrm{km}$. If we also switch off PBL mixing then we see $\mathrm{CHBr}_{3}$ especially largely confined to the lowest model level $(\sim 100 \mathrm{~m})$ and a large decrease in upper troposphere (UT) values. It may be that the studies of Nielsen and Douglass (2001) and Warwick et al. (2006) also included transport due to this process in their definition of convection. Given that turbulent mixing in the PBL can transport tracers to the lower free troposphere, then the lifetimes of $\mathrm{CHBr}_{3}$ and $\mathrm{CH}_{2} \mathrm{Br}_{2}$ would indicate that resolved vertical advection by the analysed winds could still cause some transport to the UT.

There is uncertainty in the modelled OH profile in the UT and so a sensitivity run was performed to investigate the impact of a large $(\times 2)$ change in $[\mathrm{OH}]$ on the modelled SG profiles. From the run $\mathbf{S}_{2 \mathrm{OH}}$ profile in Fig. 5 it is clear the abundance of $\mathrm{CH}_{2} \mathrm{Br}_{2}$ and associated SGI is more sensitive to changes in $\mathrm{OH}$ concentration than that of $\mathrm{CHBr}_{3}$. This is expected given the dominance of the $\mathrm{CH}_{2} \mathrm{Br}_{2}+\mathrm{OH}$ reaction over photolysis, relative to that of $\mathrm{CHBr}_{3}+\mathrm{OH}$. For the SLIMCAT run $\mathbf{S}_{\mathrm{SLIMCAT}}, \mathbf{S G}$ profiles have been scaled to approximately mimic that of the base run in the midtroposphere. It can be seen that SLIMCAT predicts a lower abundance of both SGs in the TTL and near-tropopause regions.

TOMCAT model runs with ECMWF winds have been reported previously to exhibit too rapid vertical motion in the lower stratosphere region (e.g. Chipperfield, 2006; MongeSanz et al., 2007). The problem is more obvious with ERA40 winds than that with the more recent ECMWF data sets and is mainly related to the noisy analysed wind fields. This is known to affect all CTMs using wind velocities or divergence to obtain the vertical motion (e.g. Scheele et al., 2005; Wohltman and Rex, 2008). SLIMCAT runs are not affected by the same problem as, in this case, above $350 \mathrm{~K}$ potential temperature vertical motion is computed from diagnosed heating rates. For this reason, the spurious vertical transport present in TOMCAT runs due to analysis noise is eliminated from SLIMCAT runs. In addition, SLIMCAT uses isentropic levels in the stratosphere which helps to separate vertical and horizontal motion and has also proven to provide more realistic transport in the lower stratosphere (LS) than TOMCAT (e.g. Chipperfield, 2006).

Krueger et al. (2008) performed a Lagrangian model study in the TTL region using ECMWF operational winds and found that the use of the ECMWF vertical wind field resulted in significantly faster motion than the use of computed heating rates. A study by Wolthman and Rex (2008) with ECMWF winds has also shown improvements in the vertical velocities when obtained from diagnosed heating rates with respect to the vertical velocity field from the analyses (although we do not use the vertical velocity from the analyses).

The trajectory calculation inside the TOMCAT/SLIMCAT CTM has been used to estimate the mean tracer vertical transport in the TTL in runs $\mathbf{B}$ and $\mathbf{S}_{\mathrm{SLIMCAT}}$. Trajectories were initialised at $80 \mathrm{hPa}$ (run B) and $380 \mathrm{~K}$ (run $\mathbf{S}_{\text {SLIMCAT }}$ ) and advected backwards in time using the vertical winds from the analysed divergence field and diagnosed heating rates respectively. The mean vertical motion, calculated from the trajectory displacement, was $0.64 \mathrm{~mm} / \mathrm{s}$ in run $\mathbf{B}$ and $0.324 \mathrm{~mm} / \mathrm{s}$ in run $\mathbf{S}_{\text {SLIMCAT. }}$. Analysis of $\mathrm{CO}_{2}$ data (Park et al., 2009) shows a range in vertical velocity, between the lower boundary of the TTL and the tropopause, of $0.5-0.14 \mathrm{~mm} / \mathrm{s}$.

Krueger et al. (2008) find residence times in the winter TTL (2001/2002) of 36 days using operational ECMWF with diagnosed heating rates, and only 20 days when using the corresponding ECMWF vertical winds. Our calculations show a residence time in the $360-380 \mathrm{~K}$ region of 20 days based on the TOMCAT run and 52 days based on the SLIMCAT run for the period November-December 2005. The residence times in the TTL calculated here are within the range of 20-80 days as published by WMO (2007). Our results show slower vertical transport through the TTL when using the SLIMCAT $\theta$-coordinate model with vertical transport calculated from heating rates. Given this version of the model provides overall better agreement with observations in the TTL (see below), we conclude the vertical transport from the $\theta$-coordinate model is more relastic than that of the TOMCAT p-level model. More recently, analysis of hydrochlorofluorocarbon (HCFC) and hydrofluorocarbon (HFCs) data from the WB57 aircraft during the NASA TC4 campaign indicates a transit time from $360 \mathrm{~K}$ to $380 \mathrm{~K}$ of about 3-4 months (Elliot Atlas, unpublished data). This estimate is somewhat larger than the 80 day upper limit quoted in WMO (2007) and may, in part, be due to the calculation being performed for summer months.

Overall, given the predicted mixing ratios of $\mathrm{CHBr}_{3}$ and $\mathrm{CH}_{2} \mathrm{Br}_{2}$ in the near-tropopause region, it seems the latter species may be deemed more significant. Wamsley et al. (1994) reported $\mathrm{CH}_{2} \mathrm{Br}_{2}$ to have an atmospheric lifetime long enough to reach the stratosphere and $\mathrm{CHBr}_{3}$ (with shorter lifetime) to contribute negligible amounts to stratospheric $\mathrm{Br}$. The results here are also consistent with Laube et al. (2008) who, based on observations, deduced $\mathrm{CH}_{2} \mathrm{Br}_{2}$ to be the "dominant" very short-lived SG. Their results, along with Schauffler et al. (1998), find $\mathrm{CH}_{2} \mathrm{Br}_{2}$ to be present up to $\sim 18.5 \mathrm{~km}(\sim 0.15 \mathrm{pptv})$. The results here confirm $\mathrm{CH}_{2} \mathrm{Br}_{2}$ at this level with run B predicting $\sim 0.5 \mathrm{pptv}$ and run $\mathbf{S}_{\text {SLIMCAT }} \sim 0.16 \mathrm{pptv}$. The latter seems more reasonable given the observed values discussed above, along with the overestimation of SG in the near-tropopause region by TOMCAT (see below).

The simulated model profiles of $\mathrm{CHBr}_{3}$ and $\mathrm{CH}_{2} \mathrm{Br}_{2}$ have also been compared with a variety of in-situ aircraft measurements. For the campaigns discussed herein, whole air samples were collected using evacuated canisters onboard both the DC8 and WB57 aircraft prior to analysis in the laboratory. Post flight analysis was carried out using a 5column 5-detector gas chromatography (GC) system along with two flame ionization detectors (FID) and two electron 

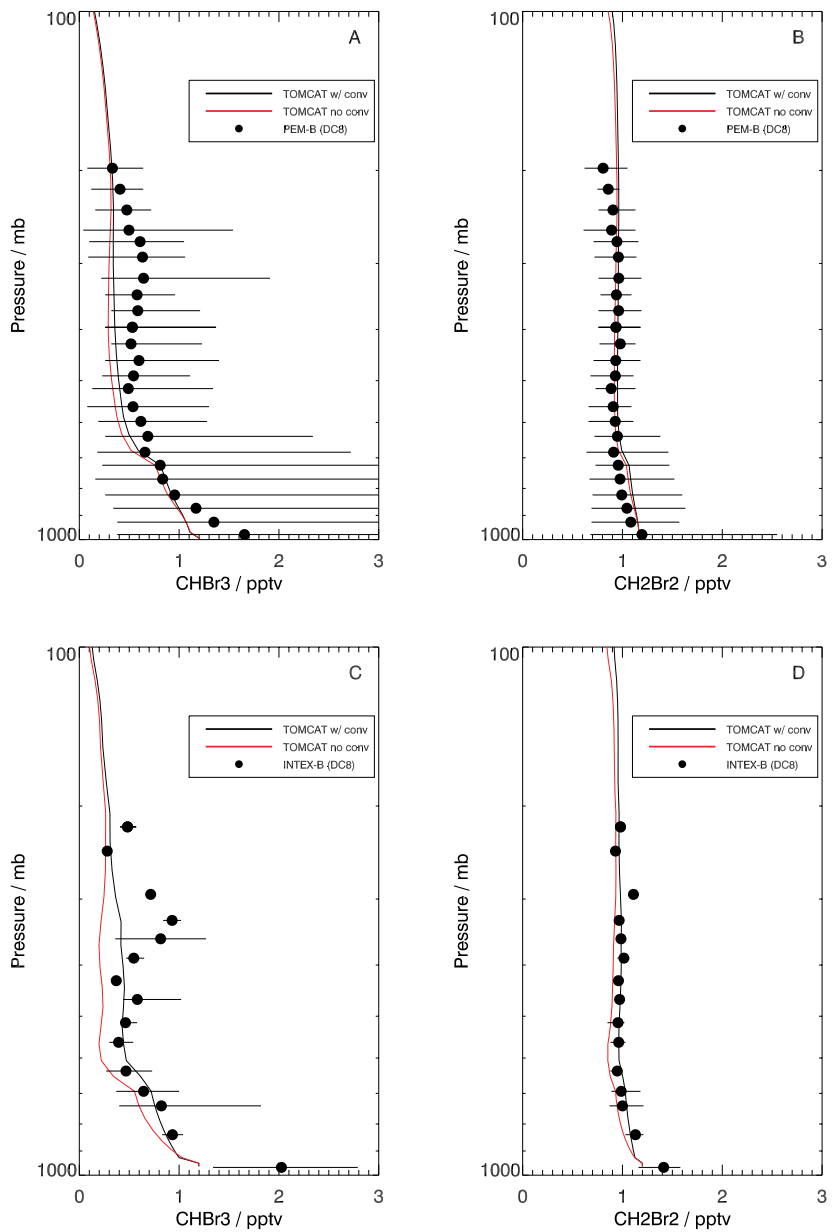

Fig. 6. Comparison of observed DC-8 profiles and model results for (a, top left) $\mathrm{CHBr}_{3}$ and (b, top right) $\mathrm{CH}_{2} \mathrm{Br}_{2}$ from the PEM TROPICS-B mission (March-April 1999). The observations have been averaged vertically in $\sim 0.5 \mathrm{~km}$ bins for tropical latitudes and between $84^{\circ}$ and $211^{\circ} \mathrm{W}$ longitude. The model (runs $\mathbf{B}$ and $\mathbf{S}_{\text {NOCONV }}$ ) is sampled over the same spatial domain and over the same months (for 2007). Panels (c) and (d) are similar plots for the NASA INTEX-B campaign (March 2006). The observations have been averaged at tropical latitudes and between $95^{\circ}$ and $99^{\circ} \mathrm{W}$ longitude. Horizontal lines on all observations denote min-max variability.

capture detectors coupled to a quadrupole mass spectrometer (MS). A discussion of the analytical techniques employed along with the accuracy and precision on measurements can be found in Colman et al. (2001). For the PEM TROPICSB campaign, precision of $\mathrm{CHBr}_{3}$ and $\mathrm{CH}_{2} \mathrm{Br}_{2}$ measurements are reported at $1.6 \%$. The accuracy is estimated to be between $1-10 \%$ at $1 \sigma$.

Figure 6 shows the modelled profiles of $\mathrm{CHBr}_{3}$ and $\mathrm{CH}_{2} \mathrm{Br}_{2}$ versus tropospheric observations from the PEM TROPICS-B (e.g. Colman et al., 2001; http://www-gte.larc. nasa.gov/pem/pemtb_obj.htm) and INTEX-B (http://www. espo.nasa.gov/intex-b/) campaigns. The model profiles
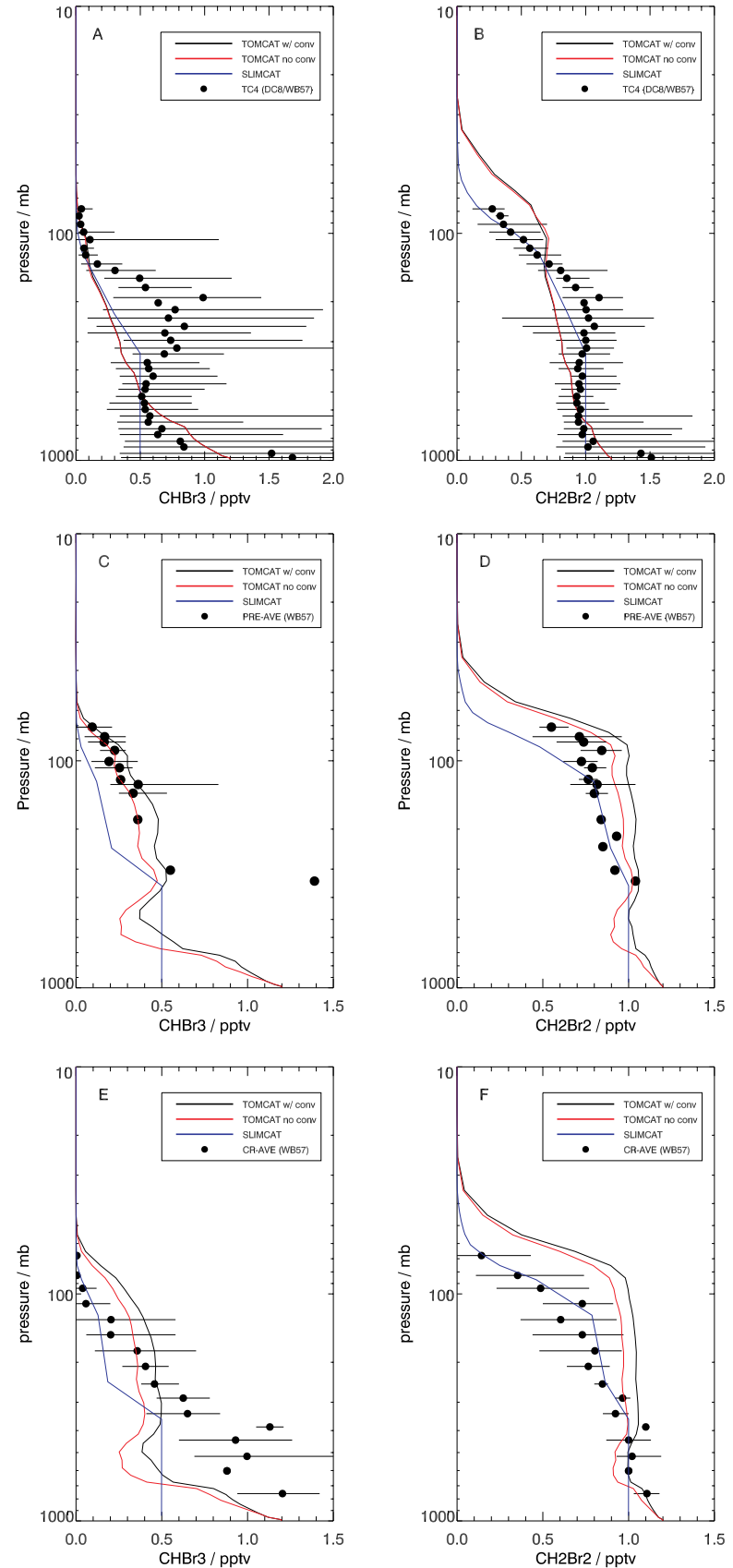

Fig. 7. Comparison of observed DC-8 and WB57 profiles and model results for (a, top left) $\mathrm{CHBr}_{3}$ and $\mathrm{CH}_{2} \mathrm{Br}_{2}$ (b, top right) from the NASA TC4 campaign (July-August 2007). Panels (c) and (d) are similar comparisons for the PRE-AVE campaign (JanuaryFebruary 2004). Panels (e) and (f) are similar comparisons for the CR-AVE campaign. (January-February 2006). The TC-4 observations have been averaged in tropical latitudes and between $70^{\circ}$ and $106^{\circ} \mathrm{W}$ longitude. The PRE-AVE observations are averaged in tropical latitudes and between $81^{\circ}$ and $85^{\circ} \mathrm{W}$ longitude. Similarly, the CR-AVE observations have been averaged at tropical latitudes and between $79^{\circ}$ and $86^{\circ} \mathrm{W}$ longitude. Horizontal lines on all observations denote min-max variability. 
shown here are averaged over the same spatial domain and for the same months (but for 2007) as the observations. This shows that the model profiles from run $\mathbf{B}$, constrained with a surface mixing ratio of $1.2 \mathrm{pptv}$ for both species, fit the observations in the mid troposphere well. Particularly, for $\mathrm{CH}_{2} \mathrm{Br}_{2}$, the model is able to reproduce observed mixing ratios and profile shape. Note that the difference between runs $\mathbf{B}$ and $\mathbf{S}_{\mathrm{NOCONV}}$ here is small, showing that modelled convection is only playing a small role in this region.

Figure 7 shows the modelled profiles of $\mathrm{CHBr}_{3}$ and $\mathrm{CH}_{2} \mathrm{Br}_{2}$ against tropical observations which extend into the TTL. These are the 2007 NASA TC-4 (http://www.espo. nasa.gov/tc4/), the NASA PRE-AVE (http://espoarchive. nasa.gov/archive/arcs/pre_ave/) campaign and the 2006 NASA CR-AVE (http://www.espo.nasa.gov/ave-costarica2/) campaigns. For TC-4 DC8 flights targeted recent convective outflow while only a single WB57 flight targeted convection. Again the model profiles are averaged over the same spatial domain and for the same months as the observations. For $\mathrm{CHBr}_{3}$, the base model $\mathbf{B}$ performs reasonably well against the observations in the lower troposphere and near the tropopause. The model is able to reproduce the gradient seen from the surface to $\sim 500 \mathrm{hPa}$ and the modelled profile lies within the min-max variability of observations at most levels. Of importance is the model's ability to simulate $\mathrm{CHBr}_{3}$ in the near-tropopause region. A number of previous model studies have significantly overestimated $\mathrm{CHBr}_{3}$ in this region when compared with observations (e.g. Warwick et al., 2006; Nielsen and Douglass, 2001). It can be seen that TOMCAT performs well in this regard. However, it seems that TOMCAT may not capture convection effectively shown by the lack of a signature "C-shape" in the profile. Results from TC4, which targeted active convective outflow during most flights, may not be representative of the region as a whole. Similarly for $\mathrm{CH}_{2} \mathrm{Br}_{2}$, the modelled profile seems reasonable against observations in the lower troposphere. There is less variability seen here than for $\mathrm{CHBr}_{3}$, due to the longer lifetime of $\mathrm{CH}_{2} \mathrm{Br}_{2}$. However, in the near-tropopause region, TOMCAT overestimates the abundance of source gas. This will be in part due to the too fast modelled vertical transport through the TTL region in run B (see above). Note that the overestimation of the SGs in the TTL in TOMCAT is not due to the model vertical resolution. The SG profiles are nearly identical in run $\mathbf{B}$ and $\mathbf{S}_{\mathrm{L} 31}$ which has the higher vertical resolution (not shown). The vertical transport is controlled by the vertical winds and not by numerical diffusion.

From Fig. 7 it is apparent that run $\mathbf{S}_{\mathrm{SLIMCAT}}$, with slower vertical transport in the TTL, reproduces observed $\mathrm{CH}_{2} \mathrm{Br}_{2}$ in the near-tropopause region fairly well and better than the TOMCAT runs. In contrast, for PRE-AVE flights, the run B profile fits $\mathrm{CHBr}_{3}$ observations well in the important upper TTL and tropopause regions. A larger difference is seen here between runs with and without convection along with more of a "C-shape" in the modelled profile. This is due to the model being sampled in the months January and Febru-

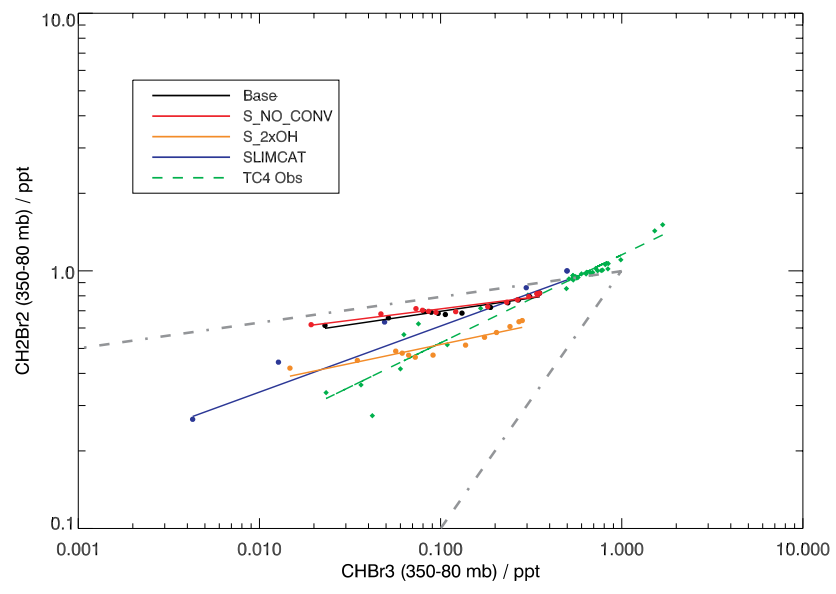

Fig. 8. Correlation plot of observed $\mathrm{CH}_{2} \mathrm{Br}_{2}$ versus observed $\mathrm{CHBr}_{3}$ between 350 and $80 \mathrm{hPa}$ from the TC-4 campaign (Fig. 7a). Also shown are model results from runs $\mathbf{B}, \mathbf{S}_{2 \mathrm{OH}}$, and $\mathbf{S}_{\text {SLIMCAT }}$ in the same region. Power lines of best fit are included on all datasets of the form, $Y=(a X)^{b}$. For an air parcel with an initial composition of 1 pptv $\mathrm{CHBr}_{3}$ and 1 pptv $\mathrm{CH}_{2} \mathrm{Br}_{2}$ the change in source gas values following (i) passive (no chemical loss) mixing with background air containing zero SGs (1:1 line) and (ii) chemical loss without mixing (assuming mean chemical lifetimes in ratio 30:300 days $\left.\left(\mathrm{CHBr}_{3}: \mathrm{CH}_{2} \mathrm{Br}_{2}\right)\right)$ are also shown (dashed grey lines).

ary when convection is stronger. The $\theta$-level model in this case seems to underestimate observed $\mathrm{CHBr}_{3}$ in the TTL, although there are few observations at this level. For $\mathrm{CH}_{2} \mathrm{Br}_{2}$, both runs $\mathbf{B}$ and $\mathbf{S}_{\text {SLIMCAT }}$ seem reasonable in the neartropopause region, with the former perhaps fitting the observations better. Unlike comparisons with TC4 and CRAVE data, run $\mathbf{B}$ does not show a significant overestimation of $\mathrm{CH}_{2} \mathrm{Br}_{2}$. This could be explained by variation in the strength of deep convective uplift between campaigns. Finally, for CR-AVE data, modelled $\mathrm{CHBr}_{3}$ is overestimated in runs $\mathbf{B}$ and $\mathbf{S}_{\text {NOCONV }}$ in the TTL and near-tropopause regions. In these regions run $\mathbf{S}_{\mathrm{SLIMCAT}}$ performs well. This is the also the case for $\mathrm{CH}_{2} \mathrm{Br}_{2}$, where the TOMCAT overestimation is greater.

Figure 8 shows a tracer-tracer plot of $\mathrm{CHBr}_{3}$ vs $\mathrm{CH}_{2} \mathrm{Br}_{2}$ in the $350-80 \mathrm{hPa}$ region from runs $\mathbf{B}, \mathbf{S}_{\mathrm{NOCONV}}, \mathbf{S}_{2 \mathrm{OH}}$ and

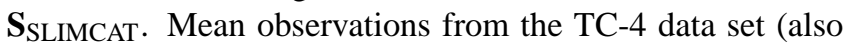
in this region, see Fig. 7a) are included on this figure along with a power line of best fit of all data sets. The origins of the model lines (high SG mixing ratios) are arbitrary and the plot tests the ability of the the different model runs to fit both SG profiles simultaneously. The model lines here indicate that with the current model setup (chemistry and transport), both tracers cannot be simulated correctly at the same time. The $\mathbf{S}_{\text {SLIMCAT }}$ run performs the best as can be seen in the gradient relative to that of the observations. This gradient of this line lies between that expected from the two extreme cases of chemical loss in an isolated air parcel ascending 

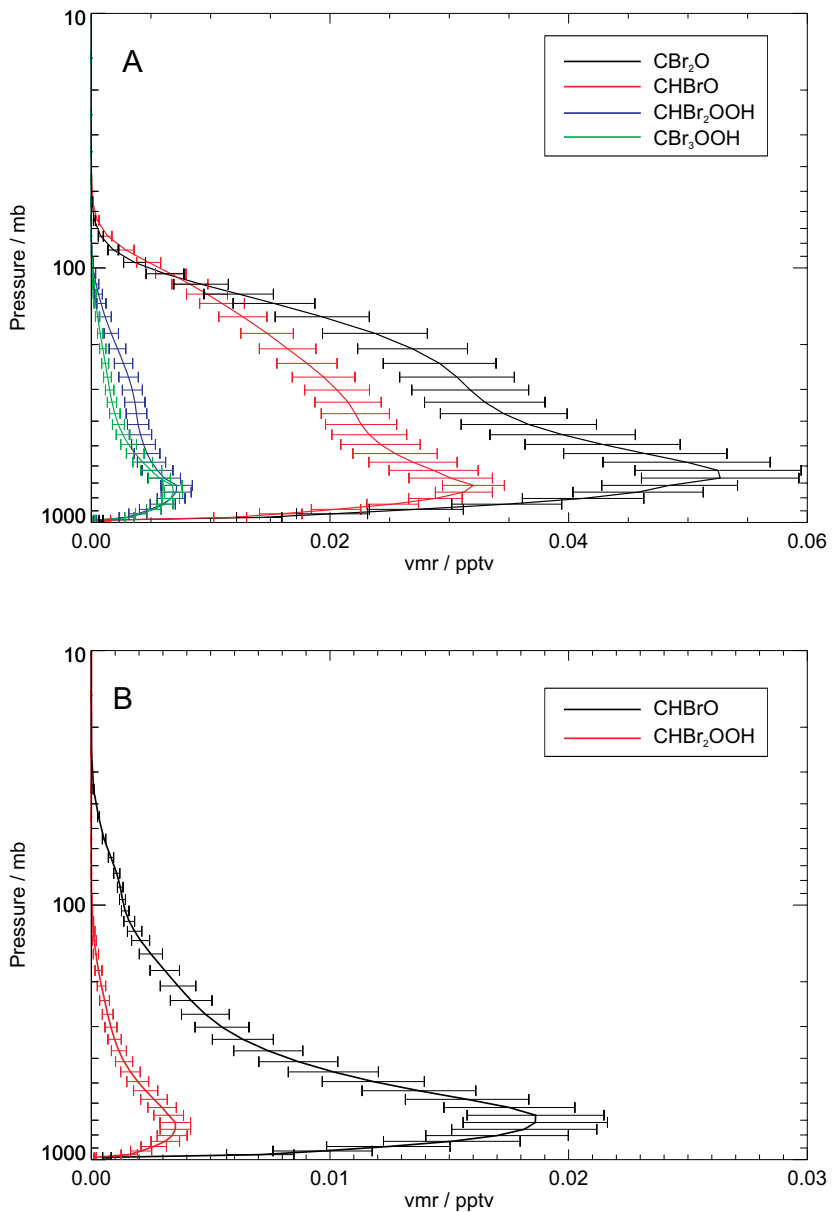

Fig. 9. Modelled tropical ( $\pm 20^{\circ}$ latitude) annual mean zonal mean profiles of the principal organic $\mathrm{PGs}$ arising from (a) $\mathrm{CHBr}_{3}$ and (b) $\mathrm{CH}_{2} \mathrm{Br}_{2}$ degradation in the tropics. The assumed surface mixing ratio of both SGs is 1 pptv. The output is from run $\mathbf{B}$ with variability in time and space shown with \pm 1 standard deviation.

in the TTL and passive mixing (i.e. without chemical loss) with air, e.g. in the extra-tropical lowermost stratosphere, containing zero $\mathrm{CHBr}_{3}$ and $\mathrm{CH}_{2} \mathrm{Br}_{2}$. This indicates that in the SLIMCAT run $\mathbf{S}_{\text {SLIMCAT }}$ mixing between the TTL and extra-tropical lowermost stratosphere has a larger effect on the TTL composition (see also discussion of $\mathrm{Br}_{\mathrm{y}}$ in Sect. 4.3). In the TOMCAT runs the gradient of the lines is much closer to that expected from the relative chemical loss. In these model runs the rapid vertical transport dominates over horizontal mixing.

\subsection{Product gas injection}

Figure 9 shows the annual tropical zonal mean abundance of the product gases arising from $\mathrm{CHBr}_{3}$ and $\mathrm{CH}_{2} \mathrm{Br}_{2}$ degradation. For bromoform the major degradation products are $\mathrm{CBr}_{2} \mathrm{O}$ and $\mathrm{CHBrO}$ with $\mathrm{CBr}_{3} \mathrm{OOH}$ and $\mathrm{CHBr}_{2} \mathrm{OOH}$ being minor products. This is consistent with the suggestions of Ko
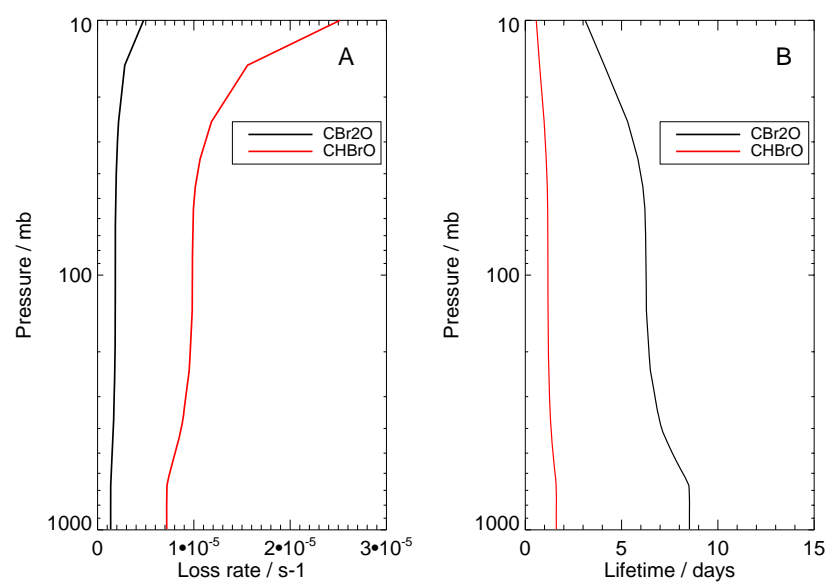

Fig. 10. Modelled tropical ( $\pm 20^{\circ}$ latitude) annual mean zonal mean profiles of (a, left) the loss rate (solely due to photolysis) and (b, right) the lifetime of $\mathrm{CBr}_{2} \mathrm{O}$ (black line) and $\mathrm{CHBrO}$ (red line).

and Poulet et al. (2003). The mixing ratios of these species in the TTL are very low $(<0.03 \mathrm{pptv})$ for the assumed SG surface vmrs. From this we infer that the contribution of these species to PGI and thus total $\mathrm{Br}$ from $\mathrm{CHBr}_{3}$ is negligible. The mixing ratios of the peroxy radicals in the scheme, $\mathrm{CBr}_{3} \mathrm{O}_{2}$ and $\mathrm{CHBr}_{2} \mathrm{O}_{2}$, were found to be near zero throughout the profile (not shown).

Similarly, for dibromomethane the model predicts the major degradation product to be $\mathrm{CHBrO}$ and a minor product to be $\mathrm{CHBr}_{2} \mathrm{OOH}$. Again, this is consistent with the suggestions of Ko and Poulet et al. (2003) and the mixing ratios of these species are also near-zero throughout the profile. As for $\mathrm{CHBr}_{3}$, it is apparent that the contribution of organic products arising from $\mathrm{CH}_{2} \mathrm{Br}_{2} \mathrm{SG}$ degradation to PGI and thus total bromine, is negligible. Furthermore, although poorly quantified, organic PGs would be expected to be removed from the atmosphere by washout processes due to their solubility. The model work described in this paper has not accounted for this and thus the extremely low near-tropopause mixing ratios reported here for $\mathrm{CBr}_{2} \mathrm{O}, \mathrm{CHBrO}$ and other PGs could indeed be overestimates. The results here suggest that PGI is dominated by the transport of inorganic products.

Figure 10 shows the calculated loss rates due to photolysis and the resultant lifetime of $\mathrm{CBr}_{2} \mathrm{O}$ and $\mathrm{CHBrO}$ in the tropics. We find $\mathrm{CBr}_{2} \mathrm{O}$ to have a lifetime of $\sim 7$ days and $\mathrm{CHBrO}$ of $\sim 1$ day due to photolysis. Overall, these results show that the assumption made in previous model studies of instantaneous conversion between organic bromine product gases and $\mathrm{Br}_{\mathrm{y}}$ following $\mathrm{SG}$ degradation seems reasonable.

\subsection{Total bromine}

Figures 11 and 12 show the modelled contribution of SGI, PGI and total $\mathrm{Br}$ delivered from $\mathrm{CHBr}_{3}$ and $\mathrm{CH}_{2} \mathrm{Br}_{2}$ degradation, respectively. Results are shown for TOMCAT sensitivity runs $\mathrm{S}_{10}, \mathrm{~S}_{20}$ and $\mathrm{S}_{40}$ (i.e. $\mathrm{Br}_{\mathrm{y}}$ lifetime of 10,20 and 

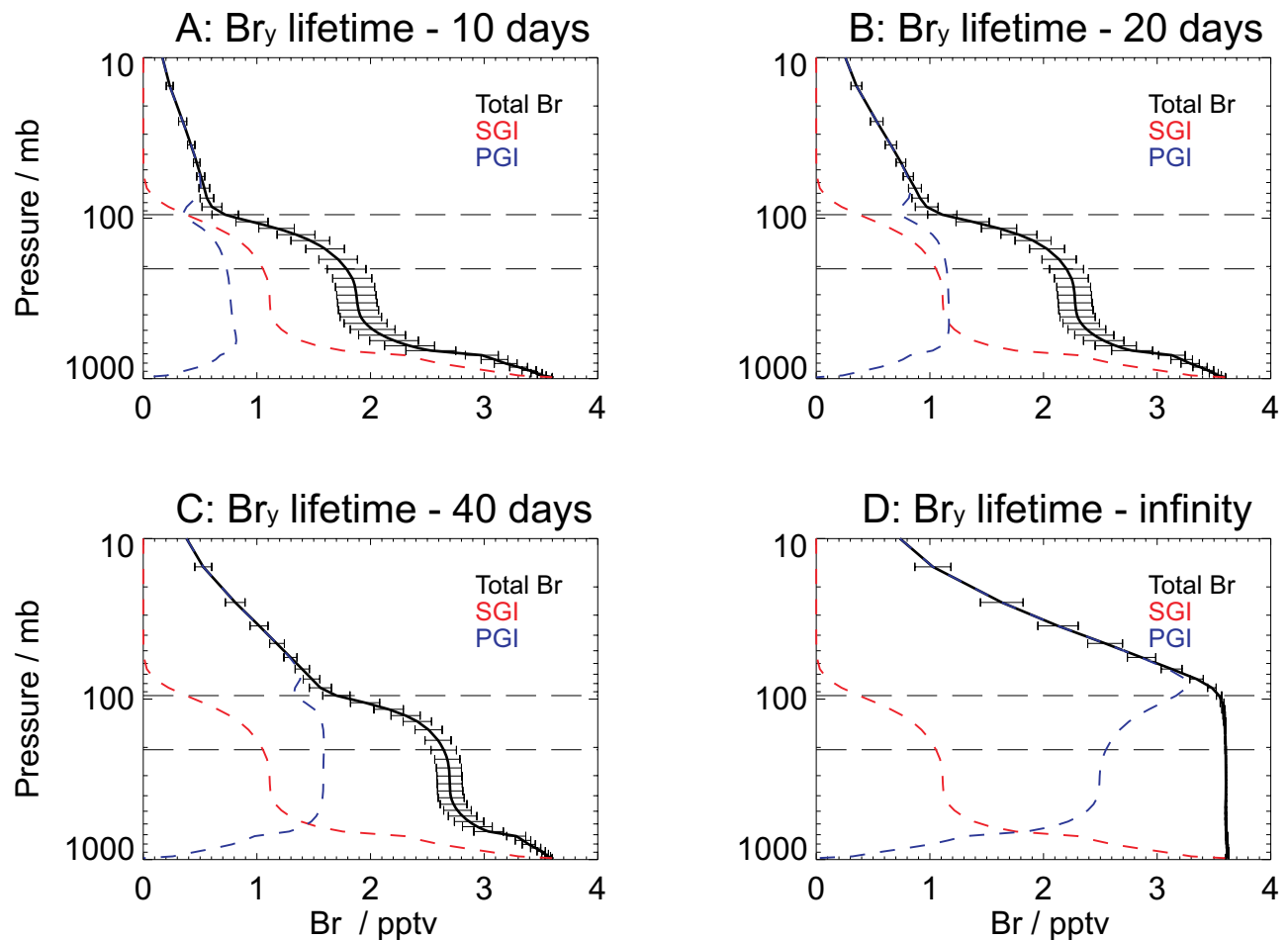

Fig. 11. Modelled tropical $\left( \pm 20^{\circ}\right.$ latitude) annual mean zonal mean profiles of SGI, PGI and total $\mathrm{Br}$ arising from $\mathrm{CHBr}_{3}$ degradation in the tropics from TOMCAT runs (a) $\mathbf{S}_{10}$, (b) $\mathbf{S}_{20}$, (c) $\mathbf{S}_{40}$ and (d) $\mathbf{B}$. These runs assume a $\mathrm{CHBr}_{3}$ surface mixing ratio of 1.2 pptv. The location of the cold-point tropopause (CPT) and base of the TTL (black dash lines) are shown for reference. Variability of total Br in time and space shown with \pm 1 standard deviation.
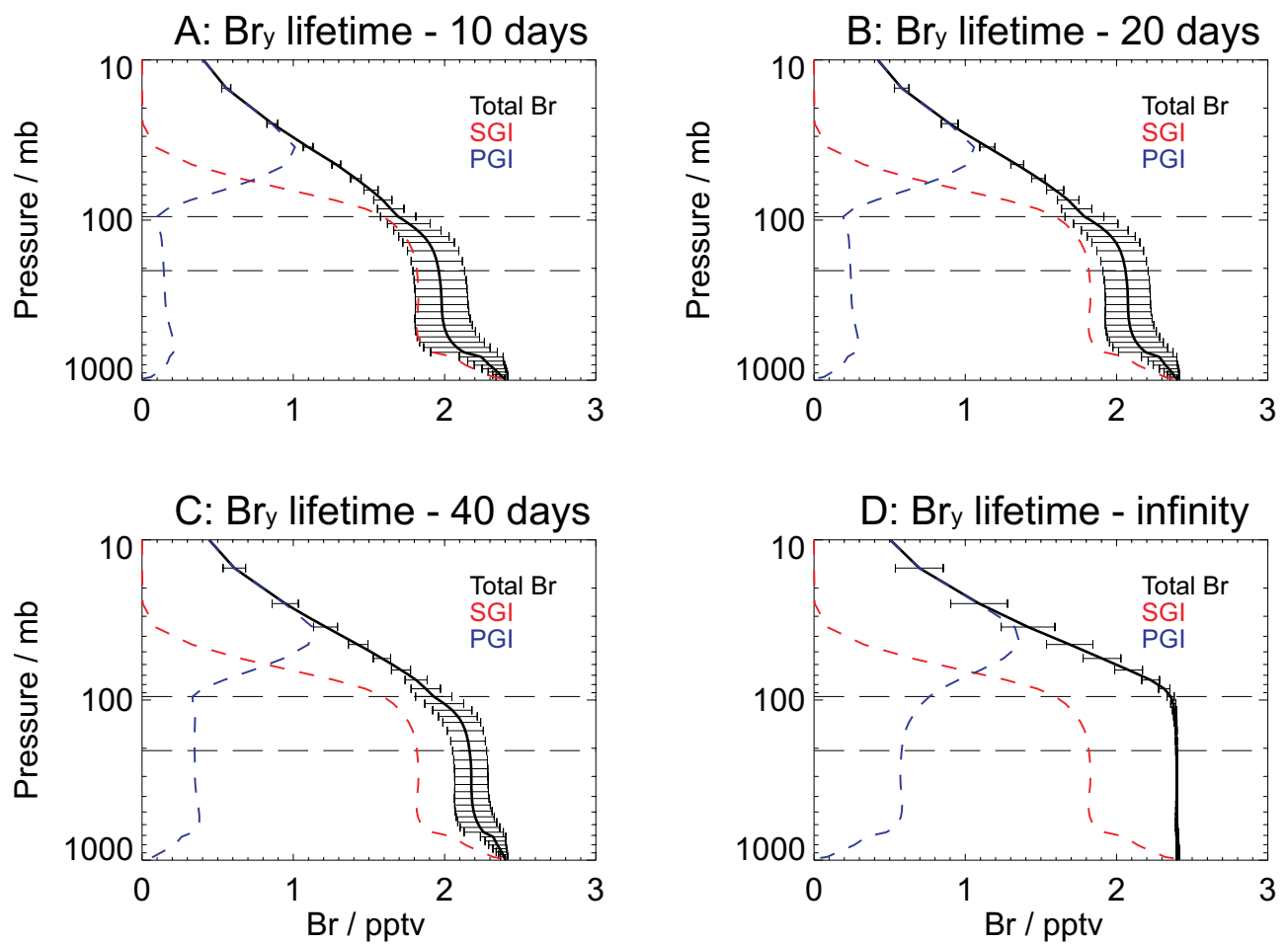

Fig. 12. As Fig. 11 but for $\mathrm{CH}_{2} \mathrm{Br}_{2}$. The assumed surface mixing ratio of $\mathrm{CH}_{2} \mathrm{Br}_{2}$ is 1.2 pptv. 
Table 5. Summary of TOMCAT modelled total Br, SGI and PGI for $\mathrm{CHBr}_{3}$ and $\mathrm{CH}_{2} \mathrm{Br}_{2}$ with $\mathrm{Br}_{\mathrm{y}}$ lifetimes of $10,20,40$ and $\infty$ days below the cold-point tropopause.

\begin{tabular}{llllll}
\hline Source Gas & Bry Lifetime & SGI/pptv & PGI/pptv & Total Br/pptv & \%SGI \\
\hline $\mathrm{CHBr}_{3}$ & 10 days & 0.377 & 0.345 & 0.722 & 53 \\
$\mathrm{CH}_{2} \mathrm{Br}_{2}$ & 10 days & 1.594 & 0.099 & 1.693 & 94 \\
Total & 10 days & 1.971 & 0.434 & $\mathbf{2 . 4 1 5}$ & 81 \\
& & & & & \\
$\mathrm{CHBr}_{3}$ & 20 days & 0.377 & 0.732 & 1.109 & 34 \\
$\mathrm{CH}_{2} \mathrm{Br}_{2}$ & 20 days & 1.594 & 0.194 & 1.788 & 89 \\
$\mathbf{T o t a l}$ & 20 days & 1.971 & 0.920 & $\mathbf{2 . 8 9 1}$ & 68 \\
$\mathrm{CHBr}_{3}$ & 40 days & 0.377 & 1.323 & 1.700 & 22 \\
$\mathrm{CH}_{2} \mathrm{Br}_{2}$ & 40 days & 1.594 & 0.334 & 1.928 & 82 \\
$\mathbf{T o t a l}$ & 40 days & 1.971 & 1.657 & $\mathbf{3 . 6 2 8}$ & 54 \\
$\mathrm{CHBr}_{3}$ & $\infty$ & 0.377 & 3.168 & $\sim 3.6$ & 11 \\
$\mathrm{CH}_{2} \mathrm{Br}_{2}$ & $\infty$ & 1.594 & 0.763 & $\sim 2.4$ & 66 \\
$\mathbf{T o t a l}$ & $\infty$ & 1.971 & 3.931 & $\sim \mathbf{6 . 0}$ & 33 \\
\hline
\end{tabular}

40 days). The base of the TTL and CPT are included for reference. Values of these fields are summarised in Table 5 and are quoted at the location of the CPT (i.e. the approximate contribution to the lower stratosphere $-\theta>380 \mathrm{~K}$ ). Note, values within the TTL are somewhat larger where quasihorizontal mixing into the extra-tropical lowermost stratosphere is possible. All results here are calculated as an annual zonal mean in the tropics. Assuming a $\mathrm{Br}_{\mathrm{y}}$ lifetime of 10 days, our TOMCAT model predicts that $\mathrm{CHBr}_{3}$ contributes $\sim 0.72$ pptv additional bromine to the lower stratosphere. We find the fraction of this value delivered via SGI and PGI to be approximately equal. This is in general agreement with the work of Dvortsov et al. (1999) and Nielsen and Douglass (2001) who report similar values of $\sim 1$ pptv. These studies also find the delivery via SGI and inorganic PGI to be approximately equal. Similarly, the results here are in good agreement with the work of Sinnhuber and Folkins (2006) who report total bromine from $\mathrm{CHBr}_{3}$ reaching the cold point to be $0.8 \mathrm{pptv}$ for the same assumed 10-day $\mathrm{Br}_{\mathrm{y}}$ lifetime. In addition, they report a PGI value of 0.3 pptv which is consistent with the $0.35 \mathrm{pptv}$ reported here.

From $\mathrm{CH}_{2} \mathrm{Br}_{2}$ and with the same 10 day $\mathrm{Br}_{\mathrm{y}}$ lifetime, we find a delivery of $\sim 1.69$ pptv of bromine to the lower stratosphere, with $\sim 94 \%$ from SGI. In this case, the contribution from PGI is small. Despite only two $\mathrm{Br}$ atoms per molecule (as opposed to 3 for $\mathrm{CHBr}_{3}$ ), the dominance of the SGI pathway is due to the longer local lifetime of $\mathrm{CH}_{2} \mathrm{Br}_{2}$, allowing more $\mathrm{SG}$ to reach the upper troposphere. The results reported here for $\mathrm{CH}_{2} \mathrm{Br}_{2}$ may constitute an upper limit given the observed overestimation of $\mathrm{SG}$ in the near-tropopause region in TOMCAT. Furthermore, we infer a total Br contribution from both SGs to be $\sim 2.4$ pptv to the lower stratosphere. Increasing the assumed $\mathrm{Br}_{\mathrm{y}}$ lifetime below the tropopause to 20 and 40 days raises this value to $\sim 2.9$ and $\sim 3.6$ pptv. The mean lifetime of $\mathrm{Br}_{\mathrm{y}}$ in the troposphere and in particular the TTL region is, however, uncertain at present.

Results from the SLIMCAT sensitivity runs indicate lower values of total $\mathrm{Br}$ from both $\mathrm{CHBr}_{3}$ and $\mathrm{CH}_{2} \mathrm{Br}_{2}$ reaching the stratosphere compared with TOMCAT (see Table 6). The results here are derived assuming a fixed $0.5 \mathrm{pptv} \mathrm{CHBr}_{3}$ and 1 pptv $\mathrm{CH}_{2} \mathrm{Br}_{2}$ in the lower 8 levels of the model (surface to $\sim 10 \mathrm{~km}$ ). These values are chosen as they mimic the mid-tropospheric values of TOMCAT profiles and also provide the best fit with aircraft observations (e.g. Fig. 7). From $\mathrm{CHBr}_{3}$, assuming a 10 day $\mathrm{Br}_{\mathrm{y}}$ lifetime, we find total $\mathrm{Br}$ reaching the stratosphere to be $\sim 0.2 \mathrm{pptv}$. Similarly for $\mathrm{CH}_{2} \mathrm{Br}_{2}$, we find a total $\mathrm{Br}$ contribution of $\sim 1.0 \mathrm{pptv}$. The lower values here result from the slower vertical motion in the SLIMCAT simulations (relative to TOMCAT) and hence a smaller SGI contribution. This slower transport would also cause a decrease in the contribution from PGI due to the increased time soluble $\mathrm{Br}_{\mathrm{y}}$ is available for washout (below the cold point tropopause). However, given the SLIMCAT simulations do not model all aspects of tropospheric tracer transport, these runs can only be seen as sensitivity tests. In addition, these SLIMCAT simulations have been performed over a period of 6 years which is not long enough for the model to spin up and reach equilibrium in the stratosphere. This can be seen in Table 6 for the run $\mathbf{S}_{\text {SLIMCAT }}$ (infinite $\mathrm{Br}_{\mathrm{y}}$ lifetime) where total $\mathrm{Br}$ values have not equilibrated at $1.5 \mathrm{pptv}$ and 2.0 pptv for $\mathrm{CHBr}_{3}$ and $\mathrm{CH}_{2} \mathrm{Br}_{2}$ respectively. This is likely due to the quasi-horizontal mixing of extra-tropical stratospheric air with low $\mathrm{Br}_{\mathrm{y}}$ content into the TTL. Note, this is not the case for the equivalent TOMCAT simulations where the model has been spun up sufficiently (see Table 5), so that total $\mathrm{Br}$ at the CPT is approximately the expected $3.6 \mathrm{pptv}$ and 2.4 pptv for $\mathrm{CHBr}_{3}$ and $\mathrm{CH}_{2} \mathrm{Br}_{2}$, respectively. 
Table 6. As Table 5 but for SLIMCAT simulations.

\begin{tabular}{|c|c|c|c|c|c|}
\hline Source Gas & $\mathrm{Br}_{\mathrm{y}}$ Lifetime & SGI/pptv & PGI/pptv & Total Br/pptv & $\%$ SGI \\
\hline $\mathrm{CHBr}_{3}$ & 10 days & 0.074 & 0.156 & 0.230 & 32 \\
\hline $\mathrm{CH}_{2} \mathrm{Br}_{2}$ & 10 days & 0.867 & 0.127 & 0.994 & 87 \\
\hline Total & 10 days & 0.941 & 0.283 & 1.224 & 77 \\
\hline $\mathrm{CHBr}_{3}$ & 20 days & 0.074 & 0.287 & 0.361 & 20 \\
\hline $\mathrm{CH}_{2} \mathrm{Br}_{2}$ & 20 days & 0.867 & 0.204 & 1.071 & 81 \\
\hline Total & 20 days & 0.941 & 0.491 & 1.432 & 66 \\
\hline $\mathrm{CHBr}_{3}$ & 40 days & 0.074 & 0.463 & 0.537 & 14 \\
\hline $\mathrm{CH}_{2} \mathrm{Br}_{2}$ & 40 days & 0.867 & 0.295 & 1.162 & 75 \\
\hline Total & 40 days & 0.941 & 0.758 & 1.699 & 56 \\
\hline $\mathrm{CHBr}_{3}$ & $\infty$ & 0.074 & 0.976 & 1.05 & 7 \\
\hline $\mathrm{CH}_{2} \mathrm{Br}_{2}$ & $\infty$ & 0.867 & 0.532 & 1.399 & 62 \\
\hline Total & $\infty$ & 0.941 & 1.508 & 2.449 & 38 \\
\hline
\end{tabular}

\section{Conclusions}

We have performed a 3-D model study using the TOMCAT/SLIMCAT CTM in order to quantify, first, the contribution of $\mathrm{CHBr}_{3}$ and $\mathrm{CH}_{2} \mathrm{Br}_{2}$ to the stratospheric bromine budget and, second, the relative magnitude of SGI and PGI. A detailed chemical scheme describing the tropospheric degradation of both source gases, along with simplified product gas chemistry, has been developed.

We have thus provided novel estimates of the organic products gases arising from $\mathrm{CHBr}_{3}$ and $\mathrm{CH}_{2} \mathrm{Br}_{2}$ degradation. The major degradation products have been found to be $\mathrm{CBr}_{2} \mathrm{O}$ and $\mathrm{CHBrO}$ whose local lifetimes are calculated at $\sim 7$ and $\sim 2$ days respectively. We find their contribution to total bromine negligible and thus infer that assumption of instantaneous production of $\mathrm{Br}_{\mathrm{y}}$ following $\mathrm{CHBr}_{3} / \mathrm{CH}_{2} \mathrm{Br}_{2}$ degradation in model studies is reasonable. It is likely that this assumption will also be valid for other short-lived source gases (e.g. $\mathrm{CHBr}_{2} \mathrm{Cl}, \mathrm{CHBrCl}_{2}$ ) whose degradation products are comparably short-lived. However, attempt at measurements of species such as $\mathrm{CBr}_{2} \mathrm{O}$ and $\mathrm{CHBrO}$ in the troposphere and TTL would certainly be useful.

The TOMCAT/SLIMCAT CTM has been shown to perform reasonably against observations of these SGs in the tropical troposphere-lower stratosphere region. The $\sigma-\theta$ level model (SLIMCAT) tends to agree better than the $\sigma-\mathrm{p}$ level model (TOMCAT) due to the slower vertical transport in the TTL. The SLIMCAT run also gives the best simultaneous relative comparisons of the profiles of $\mathrm{CHBr}_{3}$ and $\mathrm{CH}_{2} \mathrm{Br}_{2}$. We find a treatment of convection is not required in our TOMCAT simulations to transport significant quantities of SG to the TTL and lower stratosphere. In future work the convective transport parameterisation will be included in
SLIMCAT to investigate the impact of this against the background of slower resolved advection.

The results presented here have shown $\mathrm{CHBr}_{3}$ and $\mathrm{CH}_{2} \mathrm{Br}_{2}$ together could contribute around $2.4 \mathrm{pptv}$ of $\mathrm{Br}$ to the lower stratosphere when a $\mathrm{Br}_{\mathrm{y}}$ lifetime of 10 days is assumed along with mean surface mixing ratios of $1.2 \mathrm{pptv}$ for both source gases. Assuming the $\mathrm{Br}_{\mathrm{y}}^{\mathrm{VSLS}}$ value of $5 \mathrm{pptv}$ inferred by Dorf et al. (2008), then a shortfall of $\sim 2.6 \mathrm{pptv}$ remains. This may, in part, be supplied from $\mathrm{Br}$-containing SGs such as $\mathrm{CH}_{2} \mathrm{BrCl}, \mathrm{CHBr}_{2} \mathrm{Cl}$ and $\mathrm{CHBrCl}_{2}$ (local lifetimes of 150, 69 and 78 days respectively, Law and Sturges et al., 2007). However, these species are unlikely to explain a shortfall of $2.6 \mathrm{pptv}$ given their relatively low abundance in the tropical near tropopause region (e.g. Kerkweg et al., 2008). Based on a compilation of field data, Law and Sturges et al. (2007) report mixing ratios of $\mathrm{CH}_{2} \mathrm{BrCl}, \mathrm{CHBr}_{2} \mathrm{Cl}$ and $\mathrm{CHBrCl}_{2}$ in the tropical upper troposphere of $0.32(0.26-$ $0.35)$ pptv, $0.08(0.03-0.12)$ pptv and $0.12(0.05-0.15)$ pptv respectively. Furthermore, although not quantified, it is possible that "additional bromine source gases" which remain unknown may contribute (Laube et al., 2008). One uncertainty within the current model work arises on assumption of a uniform prescribed lifetime of $\mathrm{Br}_{\mathrm{y}}$ in the troposphere. In future simulations we shall couple a detailed $\mathrm{Br}_{\mathrm{y}}$ scheme, that explicitly considers the partitioning and removal of soluble products, with the degradation schemes outlined in this paper (e.g. Breider et al., 2009).

Sensitivity simulations using the SLIMCAT $\sigma-\theta$ model have shown a smaller overall contribution from $\mathrm{CHBr}_{3}$ and $\mathrm{CH}_{2} \mathrm{Br}_{2}$ to stratospheric $\mathrm{Br}$. From these runs we infer a value of $\sim 1.2 \mathrm{pptv}(0.5 \times$ the TOMCAT estimate) when assuming a 10 day lifetime of $\mathrm{Br}_{\mathrm{y}}$. Naturally this increases the 
discrepancy between the model and the value of $5 \mathrm{pptv}$ discussed above. Our results are generally in agreement with previous model work in that the contribution of brominecontaining VSLS may supply a significant amount of $\mathrm{Br}_{\mathrm{y}}$ to the lower stratosphere. Therefore, in future stratospheric simulations it will be important to take this into account.

Acknowledgements. This work was supported by the UK Natural Environment Research Council (NERC) and the EU SCOUT-O3 and SHIVA projects. RH thanks NERC for a studentship. NADR is funded via NERC NCEO. Also thanks to Sunyoung Park (Harvard University) for useful comments.

Edited by: D. Brunner

\section{References}

Arnold, S. R., Chipperfield, M. P., and Blitz, M. A.: A threedimensional model study of the effect of new temperaturedependent quantum yields for acetone photolysis, J. Geophys. Res., 110(D22), D22305 doi:10.1029/2005JD005998, 2005.

Breider, T., Chipperfield, M. P., Richards, N. A. D., Carslaw, K. S., Mann, G. W., and Spracklen, D. V.: The impact of BrO on dimethylsulfide in the remote marine boundary layer, Geophys. Res. Lett., 36, doi:10.1029/2009GL040868, in press, 2009.

Butler, J. H., King, D. B., Lobert, J. M., Montzka, S. A., YvonLewis, S. A., Hall, B. D., Warwick, N. J., Mondeel, D. J., Aydin, M., and Elkins, J. W.: Oceanic distributions and emissions of short-lived halocarbons, Global Biogeochem. Cycles, 21, GB1023, doi:10.1029/2006GB002732, 2007.

Carpenter, L. J., Jones, C. E., Dunk, R. M., Hornsby, K. E., and Woeltjen, J.: Air-sea fluxes of biogenic bromine from the tropical and North Atlantic Ocean, Atmos. Chem. Phys., 9, 1805-1816, 2009 ,

http://www.atmos-chem-phys.net/9/1805/2009/.

Colman, J. J., Swanson, A. L., Meinardi, S., Sive, B. C., Blake, D. R., and Rowland, F. S.: Description of the Analysis of a Wide Range of Volatile Organic Compounds in Whole Air Samples Collected during PEM-Tropics A and B, Anal. Chem., 73(N15), 3723-3731, 2001.

Chipperfield, M. P.: Multiannual simulations with a threedimensional chemical transport model, J. Geophys. Res., 104, 1781-1805, 1999.

Chipperfield, M. P.: A new version of the TOMCAT/SLIMCAT offline chemical transport model: Intercomparison of stratospheric tracer experiments, Q. J. Roy. Meteorol. Soc., 132, 1179-1203, doi:10.1256/qj.05.51, 2006

Dorf, M., Butz, A., Camy-Peyret, C., Chipperfield, M. P., Kritten, L., and Pfeilsticker, K.: Bromine in the tropical troposphere and stratosphere as derived from balloon-borne $\mathrm{BrO}$ observations, Atmos. Chem. Phys., 8, 7265-7271, 2008,

http://www.atmos-chem-phys.net/8/7265/2008/.

Dvortsov, V. L., Geller, M. A., Solomon, S., Schauffler, S. M., Atlas, E. L., and Blake, D. R.: Rethinking reactive halogen budgets in the mid-latitude lower stratosphere, Geophys. Res. Lett., 26, 1699-1702, 1999.

Feng, W., Chipperfield, M. P., Dorf, M., Pfeilsticker, K., and Ricaud, P.: Mid-latitude ozone changes: studies with a 3-D CTM forced by ERA-40 analyses, Atmos. Chem. Phys., 7, 2357-2369,
2007, http://www.atmos-chem-phys.net/7/2357/2007/.

Fueglistaler, S., Dessler, A. E., Dunkerton, T. J., Folkins, I., Fu, Q., and Mote, P. W.: Tropical tropopause layer, Rev. Geophys., 47, RG1004, doi:10.1029/2008RG000267, 2009.

Holtslag, A. A. M. and Boville, B.: Local versus nonlocal boundary layer diffusion in a global climate model, J. Climate, 6, 18251842, 1993.

Kerkweg, A., Jöckel, P., Warwick, N., Gebhardt, S., Brenninkmeijer, C. A. M., and Lelieveld, J.: Consistent simulation of bromine chemistry from the marine boundary layer to the stratosphere - Part 2: Bromocarbons, Atmos. Chem. Phys., 8, 5919-5939, 2008 , http://www.atmos-chem-phys.net/8/5919/2008/.

Ko, M. K. W., Poulet, G., Blake, D. R., et al.: Very short-lived halogen and sulfur substances, Scientific assessment of ozone depletion: 2002, Global Ozone Research and Monitoring Project. Report No. 47, Chapter 2, World Meteorological Organization, Geneva, 2003.

Krüger, K., Tegtmeier, S., and Rex, M.: Long-term climatology of air mass transport through the Tropical Tropopause Layer (TTL) during NH winter, Atmos. Chem. Phys., 8, 813-823, 2008 , http://www.atmos-chem-phys.net/8/813/2008/.

Laube, J. C., Engel, A., Bönisch, H., Mbius, T., Worton, D. R., Sturges, W. T., Grunow, K., and Schmidt, U.: Contribution of very short-lived organic substances to stratospheric chlorine and bromine in the tropics - a case study, Atmos. Chem. Phys., 8, 7325-7334, 2008, http://www.atmos-chem-phys.net/8/7325/2008/.

Law, K. S., Sturges, W. T., Blake, D. R., et al.: Halogenated very short-lived substances, Scientific assessment of ozone depletion: 2006, Global Ozone Research and Monitoring Project. Report No. 50, Chapter 2, World Meteorological Organization, Geneva, 2007.

McGivern, W. S., Francisco, J. S., and North, S. W.: Investigation of the atmospheric oxidation pathways of bromoform: Initiation via OH/Cl Reactions, J. Phys. Chem A., 106, 6395-6400, 2002.

McGivern, W. S., Hahkjoon, K., Francisco, J. S., and North, S. W. Investigation of the atmospheric oxidation pathways of bromoform and dibromomethane: Initiation via UV photolysis and hydrogen abstraction, J. Phys. Chem A., 108, 7247-7252, 2004.

Monge-Sanz, B., Chipperfield, M. P., Simmons, A., and Uppala, S.: Mean age of air and transport in a CTM: Comparison of different ECMWF analyses, Geophys. Res. Lett., 34, L04801, doi:10.1029/2006GL028515, 2007.

Moortgat, G. K., Meller, R., and Schneider, W.: Temperature dependence $(256-296 \mathrm{~K})$ of the absorption cross-sections of bromoform in the wavelength range $285-360 \mathrm{~nm}$, in: The Tropospheric Chemistry of Ozone in the Polar Regions, NATO ASI Series, Vol. I7, edited by: Niki, H. and Becker, K. H., 359-369, Springer Verlag, Berlin, 1993.

Nielsen, J. E. and Douglass, A. R.: A simulation of bromoform's contribution to stratospheric bromine, J. Geophys. Res., 106, 8089-8100, 2001.

Park, S., Atlas, E. L., Jimenez, R., Daube, B. C., Gottleib, E. W., Nan, J., Jones, D. B. A, Pfister, L., Conway, T. J., Bui, T. P., Gao, R., and Wofsy, S. C.: Vertical transport rates for the tropical tropopause layer from observations of $\mathrm{CO}_{2}$ : Implications for distributions of long-and short-lived chemical species, in prepa- 
ration, 2010.

Prather, M. J.: Numerical advection by conservation of secondorder moments, J. Geophys. Res., 91, 6671-6681, 1986.

Quack, B. and Wallace, D. W. R.: Air-sea flux of bromoform: Controls, rates, and implications, Global Biogeochem. Cy., 17(1), 1023, doi:10.1029/2002GB001890, 2003.

Salawitch, R. J., Weisenstein, D. K., Kovalenko, L. J., Sioris, C. E., Wennberg, P. O., Chance, K., Ko, M. K. W., and McLinden, C. A.: Sensitivity of ozone to bromine in the lower stratosphere, Geophys. Res. Lett., 32, L05811, doi:10.1029/2004GL021504, 2005.

Sander, S. P., Friedl, R. R., Golden, D. M., Kurylo, M. J., Moortgat, G. K., Keller-Rudek, H., Wine, P. H., Ravishankara, A. R., Kolb, C. E., Molina, M. J., Finlayson-Pitts, B. J., Huie, R. E., and Orkin, V. L.: Chemical Kinetics and Photochemical Data for Use in Atmospheric Studies, Evaluation Number 15, JPL Publication 06-2, Jet Propulsion Laboratory, Pasadena, CA, 2006.

Schauffler, S. M., Atlas, E. L., Flocke, F., Lueb, R. A., Stroud, V., and Travnicek, W.: Measurements of bromine containing organic compounds at the tropical tropopause, Geophys. Res. Lett., 25(3), 317-320, 1998.

Scheele, M. P., Siegmund, P. C., and Velthoven, P. F. J.: Stratospheric age of air computed with trajectories based on various 3D-Var and 4D-Var data sets, Atmos. Chem. Phys., 5, 1-7, 2005, http://www.atmos-chem-phys.net/5/1/2005/.

Sinnhuber, B.-M. and Folkins, I.: Estimating the contribution of bromoform to stratospheric bromine and its relation to dehydration in the tropical tropopause layer, Atmos. Chem. Phys., 6, 4755-4761, 2006,

http://www.atmos-chem-phys.net/6/4755/2006/.
Stockwell, D. Z. and Chipperfield, M. P.: A tropospheric chemical transport model: Development and validation of the model transport schemes, Q. J. Roy. Meteorol. Soc., 125, 1747-1783, 1998.

von Glasow, R., von Kuhlmann, R., Lawrence, M. G., Platt, U., and Crutzen, P. J.: Impact of reactive bromine chemistry in the troposphere, Atmos. Chem. Phys., 4, 2481-2497, 2004, http://www.atmos-chem-phys.net/4/2481/2004/.

Wamsley, P. R., Elkins, J. W., Fahey, D. W., Dutton, G. S., Volk, C. M., Myers, R. C., Montzka, S. A., Butlet, J. H, Clarke, A. D., Fraser, P. J., Steele, L. P., Lucarelli, M. P., Atlas, E. L., Schauffler, S. M., Blake, D. R., Rowland, F. S., Sturges, W. T., Lee, J. M., Penkett, S. A, Engel, A., Stimpfle, R. M., Chan, K. R., Weisenstein, D. K., Ko, M. K. W, and Salawitch, R. J.: Distribution of halon-1211 in the upper troposphere and lower stratosphere and the 1994 total bromine budget, J. Geophys. Res., 103(D1), 1513-1526, 1998.

Warwick, N. J., Pyle, J. A., Carver, G. D., Yang, X., Savage, N. H., O'Connor, F. M., and Cox, R. A.: Global modeling of biogenic bromocarbons, J. Geophys. Res., 111, D24305, doi:10.1029/2006JD007264, 2006.

Wohltmann, I. and Rex, M.: Improvement of vertical and residual velocities in pressure or hybrid sigma-pressure coordinates in analysis data in the stratosphere, Atmos. Chem. Phys., 8, 265 272, 2008, http://www.atmos-chem-phys.net/8/265/2008/.

WMO (World Meteorological Organization), Scientific Assessment of Ozone Depletion: 2006, Global Ozone Research and Monitoring Project - Report No. 50, 572 pp., Geneva, Switzerland, 2007. 